Research article

\title{
Mechanisms and age estimates of continental-scale endorheic to exorheic drainage transition: Douro River, Western Iberia
}

\author{
Pedro P. Cunha ${ }^{\mathrm{a}, *}$, António A. Martins ${ }^{\mathrm{b}}$, Alberto Gomes ${ }^{\mathrm{c}}$, Martin Stokes ${ }^{\mathrm{d}}$, João Cabral ${ }^{\mathrm{e}}$, \\ Fernando C. Lopes ${ }^{f}$, Diamantino Pereira ${ }^{g}$, Gerardo de Vicente $^{\mathrm{h}}$, Jan-Pieter Buylaert ${ }^{\mathrm{i}}$, \\ Andrew S. Murray ${ }^{j}$, Loreto Antón ${ }^{\mathrm{k}}$ \\ ${ }^{\mathrm{a}}$ MARE - Marine and Environmental Sciences Centre, Department of Earth Sciences, University of Coimbra, Rua Sílvio Lima, Univ. Coimbra - Pólo II, $3030-790$ Coimbra, \\ Portugal \\ ${ }^{\mathrm{b}}$ ICT - Institute of Earth Sciences, Department of Geosciences, University of Évora, Rua Romão Ramalho, 59, 7000-671 Évora, Portugal \\ ${ }^{\mathrm{c}}$ CEGOT, Department of Geography, University of Porto, Via Panorâmica s/n, 4159-564 Porto, Portugal \\ ${ }^{\mathrm{d}}$ School of Geography, Earth and Environmental Sciences, University of Plymouth, Plymouth, UK \\ ${ }^{\mathrm{e}}$ Instituto Dom Luiz, Departamento de Geologia, Faculdade de Ciências, Universidade de Lisboa, 1749-016 Lisboa, Portugal \\ ${ }^{\mathrm{f}}$ CITEUC, Department of Earth Sciences, University of Coimbra, Rua Sílvio Lima, Univ. Coimbra - Pólo II, 3030-790 Coimbra, Portugal \\ ${ }^{g}$ ICT - Institute of Earth Sciences, Department of Earth Sciences, University of Minho, Campus de Gualtar, 4710-057 Braga, Portugal

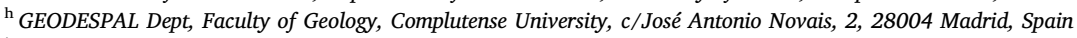 \\ ${ }^{\mathrm{i}}$ Centre for Nuclear Technologies, Technical University of Denmark, Risø Campus, Denmark \\ ${ }^{\mathrm{j}}$ Nordic Laboratory for Luminescence Dating, Aarhus University, Risø DTU, Denmark \\ ${ }^{\mathrm{k}}$ Departamento de Ciencias Analíticas, Facultad de Ciencias, Universidad Nacional de Educación a Distancia, Madrid, Spain
}

\section{A R T I C L E I N F O}

\section{Keywords:}

Western Iberia

Transverse drainage

Basin overspill

Incision rate

Terrace staircase

Luminescence dating

\begin{abstract}
A B S T R A C T
In western Iberia, mechanisms that can explain the transition from endorheic to exorheic continental-scale drainage reorganization are foreland basin overspill, headwards erosion and capture by an Atlantic river, or a combination of both. To explore these, we have investigated the Portuguese sector of the Douro River, the locus of drainage reorganization. The Douro River is routed downstream through the weak sedimentary infill of the Douro Cenozoic Basin, after which the river cuts down through harder granitic and metamorphic rocks crossed by active fault zones, before reaching the Atlantic coast. We investigated the drainage reorganization using an integrated approach that combined remote sensing, field survey and geochronology, applied to Pliocene-Quaternary fluvial sediments and landforms. The older drainage record is documented by a series of high and intermediate landform levels comprising: (1) a high level (1000-500 $\mathrm{m}$ a.s.l.) faulted regional fluvial erosion surface, the North Iberian Meseta planation surface and the Mountains and Plateaus of Northern Portugal, recording the endorheic drainage of the Douro Cenozoic Basin; (2) a first inset level at 650-600 m a.s.l., comprising a broad fluvial surface developed onto a large ENE-WSW depression, interpreted as recording the initiation of the continental scale reorganization; and (3) an inset fluvial surface at 550-400 m a.s.1., corresponding to the establishment of the exorheic ancestral Douro valley. The younger drainage record comprises an entrenched fluvial strath terrace sequence of up to 9 levels (T9 = oldest), positioned at 246-242 $\mathrm{m}$ above the modern river base; $\mathrm{T} 1$ = youngest, positioned at $+17-13 \mathrm{~m}$. Levels $\mathrm{T} 1$ and $\mathrm{T} 3$ display localized fault offsets. The three lowest terrace levels (T3-T1) were dated using optically stimulated luminescence techniques with results ranging from $>230-360 \mathrm{ka}$ (T3), through $57 \mathrm{ka}$ (T2) to 39-12 ka (T1). Fluvial incision rates of the younger terraces were quantified and temporally extrapolated to model the ages of the intermediate to high elevation levels of the early drainage record. Integration of incision data informs on the probable timing of the drainage reorganization and the initial adjustment, $\sim 3.7-1.8 \mathrm{Ma}$. This was followed by acceleration of incision, producing the entrenched river terrace sequence developed via spatial and temporal variations in rock strength, uplift and cyclic cool-climate variability as the river adjusted to the Atlantic base level.
\end{abstract}

\footnotetext{
* Corresponding author.

E-mail addresses: pcunha@dct.uc.pt (P.P. Cunha), aam@uevora.pt (A.A. Martins), M.Stokes@plymouth.ac.uk (M. Stokes), jcabral@fc.ul.pt (J. Cabral), fcarlos@dct.uc.pt (F.C. Lopes), insud@dct.uminho.pt (D. Pereira), gdv@geo.ucm.es (G. de Vicente), jabu@dtu.dk (J.-P. Buylaert), anmu@dtu.dk (A.S. Murray), lanton@ccia.uned.es (L. Antón).
} 


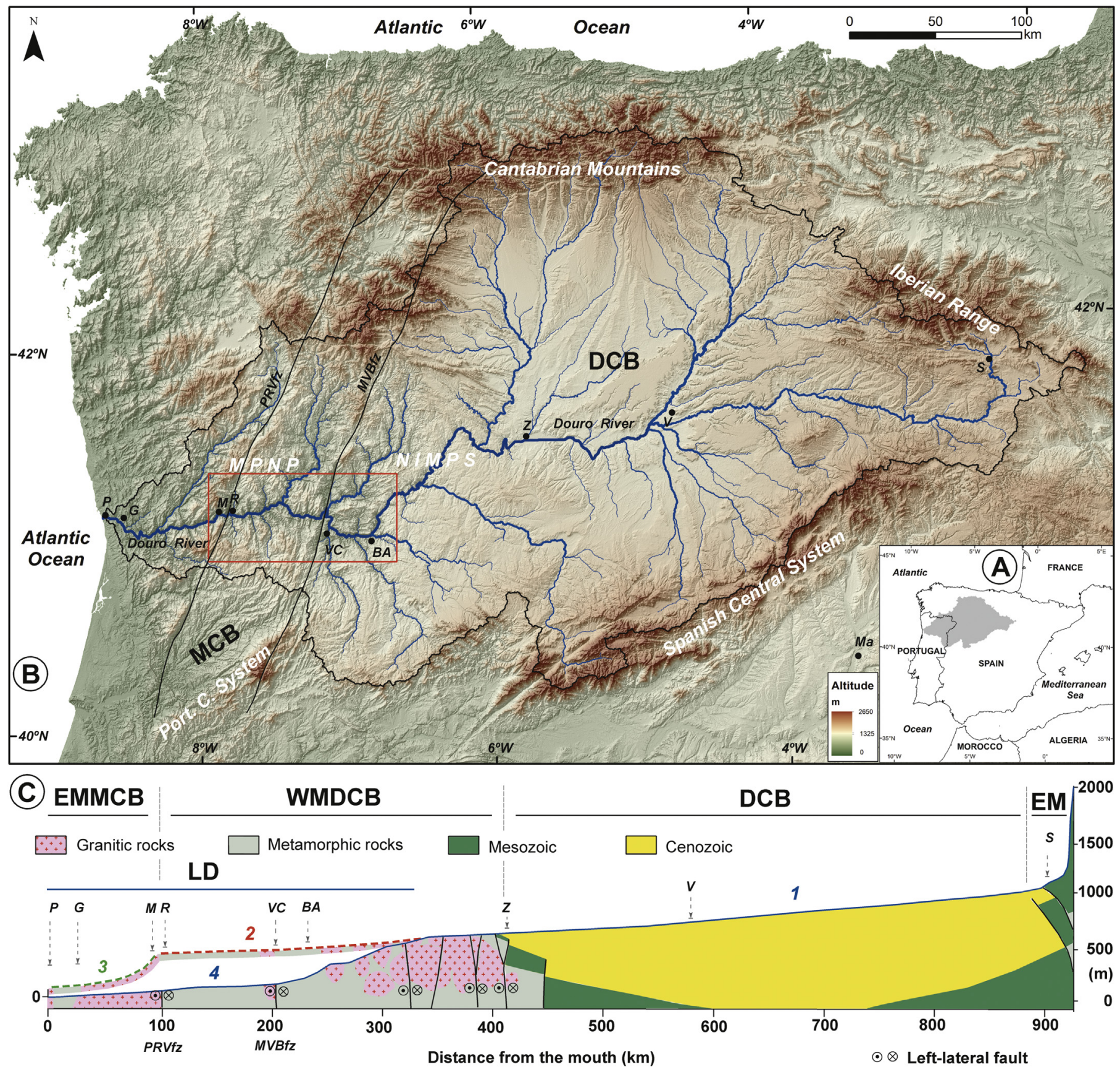

Fig. 1. The Douro catchment (drainage divide = black line) and its drainage network (blue lines) (B), inset showing location in Iberia (A) and longitudinal profile (C) with bedrock geology relationships. EM - eastern margin of the Douro Cenozoic Basin; DCB - Douro Cenozoic Basin; WMDCB - western margin of the Douro Cenozoic Basin; EMMCB - eastern margin of the Mondego Cenozoic Basin; MCB - Mondego Cenozoic Basin; MPNP - Mountains and Plateaus of Northern Portugal; NIMPS North Iberian Meseta planation surface; MVBfz - Manteigas-Vilariça-Bragança fault zone; PRVfz - Penacova-Régua-Verín fault zone; LD - Lower Douro; 1 - long profile of the Douro River in the DCB; 2 - long profile of the ancestral Douro in the study area; 3 - long profile of an ancestral coastal Atlantic river; 4 - long profile of the modern Douro downstream of the DCB; P - Porto; G - Gondomar; M - Mesão Frio; R - Régua; VC - Vila Nova de Foz Côa; BA - Barca d'Alva; Z - Zamora; V - Valladolid; S - Soria; Ma - Madrid; Red rectangle on (B) - study area. (For interpretation of the references to colour in this figure legend, the reader is referred to the web version of this article.)

\section{Introduction}

Continental areas with internal drainage adjacent to oceanic regions can reconnect with marine base level by (i) overspill of the internal drainage into an adjacent river system with marine base level connection (e.g, Heidarzadeh et al., 2017) or (ii) capture from adjacent river systems already linked to a marine base level (e.g., Stokes and Mather, 2003). Such switches from internal (endorheic) to external (exorheic) drainage can result in significant drainage network re-organisation, including marked changes in drainage routing and substantial fluvial inicision and erosion in the area where overspill or capture has occurred. This incision then propagates upstream into the former endorheic system as it equilibrates with the newly connected and lower marine base level.

The study of how rivers that cut transversely through mountains or plateaus has seen a significant resurgence in the last two decades, using field and modelling approaches (e.g., Young and Spamer, 2001; Stokes and Mather, 2003; Twidale, 2004; Douglass et al., 2009; Larson et al., 
2017). These studies show that the development of transverse drainage can often lead to re-organisation of catchments, allowing formerly internally drained basins to switch to externally draining systems. The process by which this transformation occurs is commonly attributed to the mechanisms of antecedence, superimposition, overflow (overspill) or piracy (capture). However, the timing and mechanisms, as well as the role of the possible interplay between surface and tectonic processes, are a matter of debate in most cases. This is because the drainage development process is typically dominated by erosion, resulting in an incomplete or missing record. As stated by Heidarzadeh et al. (2017), the typically proposed mechanisms are basin overspill (a top-down process) and headward erosion (a bottom-up process), but the lack of unequivocal diagnostic criteria for distinguishing between such mechanisms can hamper understanding. However, using integrated remote sensing, fieldwork, geochronological and modelling approaches in the study of fragmentary fluvial landscape elements can yield valuable insights into the mechanisms and rates at which transverse drainage developed.

Continental Cenozoic basins that underwent an endorheic to exorheic transition are reported in several Iberian river systems, encompassing a wide range of spatial and temporal scales (e.g., Mather, 2000; Stokes et al., 2002, 2018; Stokes, 2008; Soria-Jáuregui et al., 2018; Struth et al., 2019). These studies illustrate that the best interpretative model of the mechanism driving the endorheic-exorheic drainage reorganization should be based on the integration of detailed geological and geomorphological studies using the trunk river and, if necessary, its tributaries. Once the exorheism has been established, the patterns and rates of adjustment can be investigated using dated river terraces (e.g., Silva et al., 2017).

In this paper we focus on continental-scale drainage reorganization in an intraplate setting using the largest Iberian drainage system, the Douro River (Duero in Spain). The catchment of the Douro comprises a continental foreland Cenozoic basin that underwent an endorheic to exorheic transition. The complexity of the interpretation concerning the initiation and evolution of the Douro River was first presented by Lautensach $(1932,1987)$. Transverse drainage has been proposed to have developed from antecedance (erosional downcutting by an already existing river system) (Ferreira, 1978) or by drainage reorganization through headward erosion and capture (e.g., Feio, 1951; Ferreira, 1986; Martín Serrano, 1991; Antón et al., 2018; Struth et al., 2019). Overspill has not been explored hitherto as an explanation of Douro drainage evolution.

Most interpretations of the transition of the previously endorheic Cenozoic basins of central Iberia (e.g., Douro and Madrid Cenozoic basins) to Atlantic drainage systems have suggested that headward erosion by Atlantic fluvial systems captured the central Iberia drainage and eventually triggered drainage reversal (e.g., Gutierrez-Elorza and Pérez-González, 1993; Alonso-Gavilán et al., 2004 and references therein). However, other studies of Iberian river systems have shown that similar drainage evolution may be instigated by a combination of aqueous overflow of the basin and by capture-related headward erosion (e.g., Ebro Basin; Garcia-Castellanos et al., 2003). Also, the transition from endorheic to exorheic drainage in the Madrid Cenozoic Basin is considered to have occured by overspill into the Lower Tejo Cenozoic Basin, at $\sim 3.7 \mathrm{Ma}$, as evidenced by a culminant sedimentary unit (Cunha, 1992a, 2019); the later stage of fluvial incision associated with the River Tejo (Tagus) began as recently as $\sim 2 \mathrm{Ma}$ (Cunha et al., 2016, Cunha et al., 2012; Silva et al., 2017).

The study area (Freixo de Espada à Cinta - Régua), comprising the upstream part of the Lower Douro catchment (Figs. 1, 2 and 3), is crucial for understanding the regional transition from endorheic to exorheic drainage, due to its location between the previously endorheic Douro Cenozoic Basin and the Atlantic drainage of the Mondego Cenozoic Basin (Cunha, 2019).

More broadly, the study area also allows the formation and destruction of a low-relief plateau morphology to be addressed. Changes in climate or in the locus of tectonic activity can lead to disequilibrium conditions, a potential trigger for rapid destruction of the plateau morphology via fluvial incision (Meek and Douglass, 2001; House et al., 2008; Craddock et al., 2010; Heidarzadeh et al., 2017).

In several reaches of the study area, the Douro shows two high fluvial erosion levels at $650-600 \mathrm{~m}$ and $500-450 \mathrm{~m}$ above sea level (a.s.l.) that are inset into the regional planation surface and above a staircase of strath terraces (fluvially eroded benches that are etched into bedrock) (Ferreira, 1971, 1978). The lower-level strath terraces are capped by a veneer of fluvial sediment that enabled a degree of chronological control for the endorheic-exhoreic transition process using luminescence dating. The geomorphological data and dating of the terrace deposits provides temporal estimates for fluvial aggradation and quantification of fluvial incision rates. The collective integration of terrace incision rates is then used to evaluate differential crustal uplift. Collectively, this work informs on the timing and the controlling mechanisms of the transition from endorheic to exorheic drainage in the Douro Basin, which were hitherto poorly constrained because of a lack of geomorphological studies integrating detailed fieldwork and absolute dating of sedimentary deposits and landforms.

\section{Geomorphological and geological background}

The Douro is one of the longest Iberian rivers $(\sim 927 \mathrm{~km})$, with a source at $1700 \mathrm{~m}$ a.s.l. in the "Sierra de Urbión" (Iberian Range, Spain) and its mouth at Porto, on the Atlantic coast of Portugal (Fig. 1). The drainage basin covers approximately $97,290 \mathrm{~km}^{2}$, with $80 \%$ in Spain and the remaining 20\% in Portugal (e.g., Tockner et al., 2009).

The long profile gradient of the modern Douro River varies as it crosses different geological regions. In the Iberian Ranges, within its uppermost reach, the profile has a steep gradient coincident with Mesozoic bedrock (Fig. 1). Downstream, it has a classic 'graded-profile' shape as the Douro crosses through the sedimentary infill of the Douro Cenozoic Basin. Here, the river is incised by $20-200 \mathrm{~m}$ below the basin surface (e.g. Antón et al., 2012 and references therein). The trunk river and its tributaries display low-gradient, concave profiles with valleys characterized by well-developed river terrace staircases (e.g. Silva et al., 2017). The downstream sector along the western margin of the Douro Cenozoic Basin is an extensive low-to-high relief faulted area at 500-1000 m a.s.l., corresponding to the North Iberian Meseta planation surface (NIMPS) (Ficher, 1894; Hernandez-Pacheco, 1911; Dantin, 1912; Lautensach, 1932; Solé, 1952) and the Mountains and Plateaus of Northern Portugal (MPNP) (Ferreira, 1978, 1980; Galve et al., 2019) (Fig. 1). Downstream to the west of the Montemuro-Marão-Alvão relief barrier, the regional elevation is lower and records the ancestral drainage route towards the Mondego Cenozoic Basin (Figs. 1, 2 and 3).

Along the North Iberian Meseta planation surface, the Douro is incised into granite bedrock, forming a $150 \mathrm{~km}$ long knick zone. Here, it flows through deeply incised gorges (Arribas do Douro), with up to $600 \mathrm{~m}$ of incision recorded at the Águeda-Douro confluence (Antón et al., 2012, 2014, 2015, 2018). Along the Lower Douro ( $\sim 230 \mathrm{~km})$, the river flows aproximately E-W from the Águeda confluence to the Atlantic coast. Its valley is incised into metamorphic and granitic basement, displaying an almost graded lower gradient, v-shaped form (Figs. 1, 2 and 3).

The Arribas do Douro knick zone (Figs. 1, 2 and 3) represents a resistant lithological threshold limiting upstream headward erosion from the Atlantic Ocean, thus acting as a local lithological base level for the upstream area, controlling the depth of incision and rate of headward erosion into the weaker sedimentary rocks of the Douro Cenozoic Basin (e.g. Martín Serrano, 1991, 1994).

The sedimentary infill of the Douro Cenozoic Basin mainly comprises Paleogene to Late Miocene fluvial to lacustrine arkoses, siltyclays and limestones the top unit of this succession is the Páramo Formation, dated as 9.7-9.6 Ma by Krijgsman et al. (1996), but also upper Tortonian to early Pleistocene alluvial fan gravels and sands (e.g. 


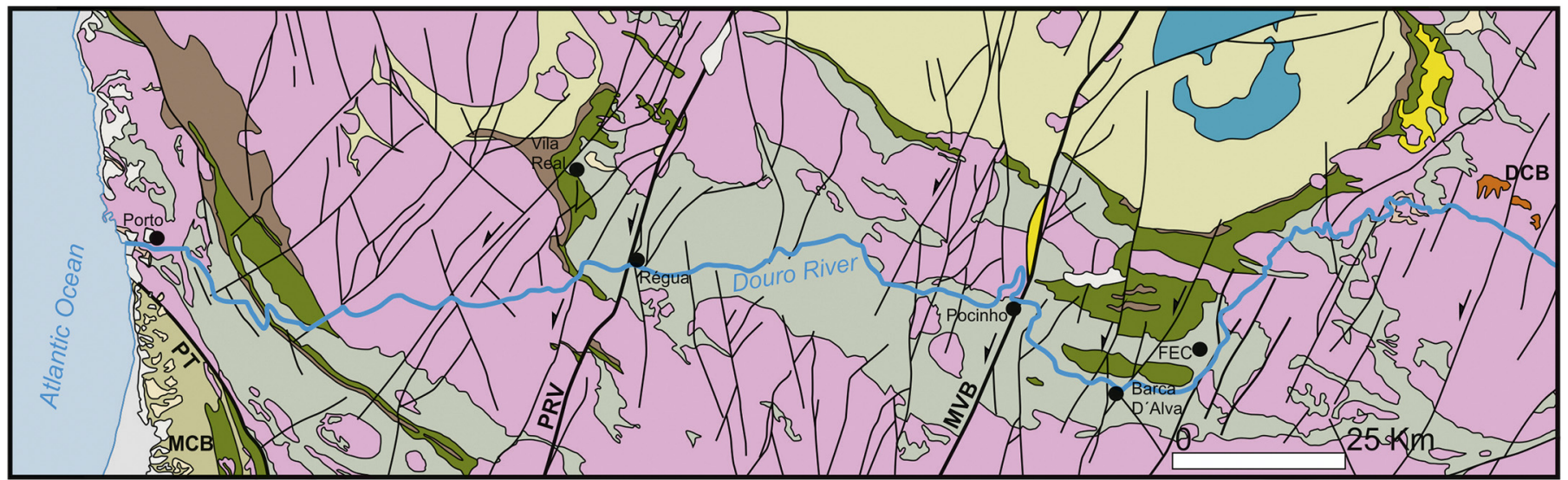

\begin{tabular}{l|ll} 
Granites and granitoids (Pre-syn-post Variscan) & Holocene \\
Ophiolites (Mid. Devonian - Ordovician) & Fault \\
Shales (Silurian) & Pleistocene \\
Quartzites, shales (Ordovician) & Pliocene \\
\cline { 2 - 2 } Schists, graywackes, quartzites (Proterozoic-Cambrian) & Miocene \\
Gneisses, schists (Proterozoic) & Paleogene
\end{tabular}

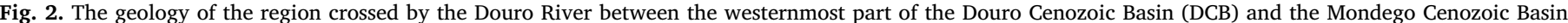

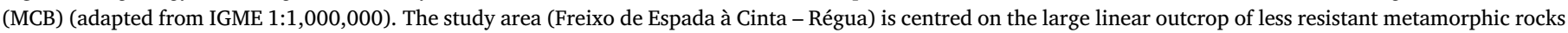

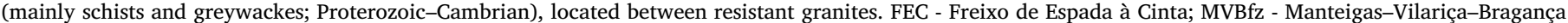
fault zone; PRVfz - Penacova-Régua-Verín fault zone; PT - Porto-Tomar faut zone.

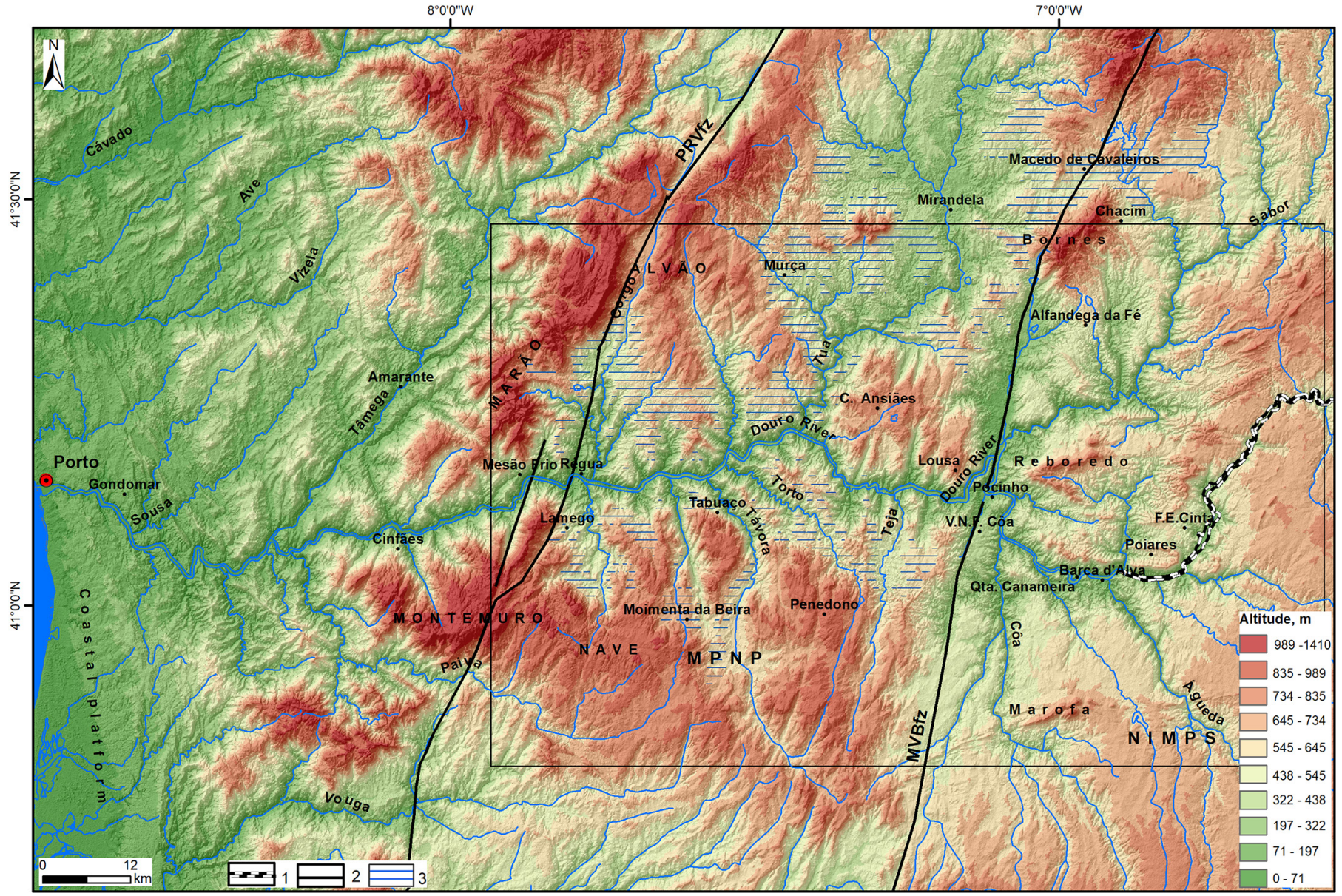

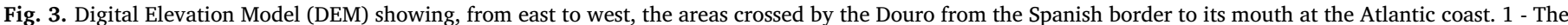

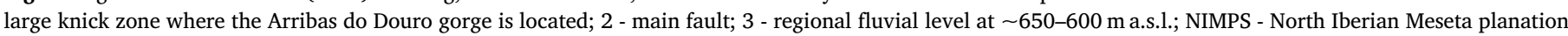

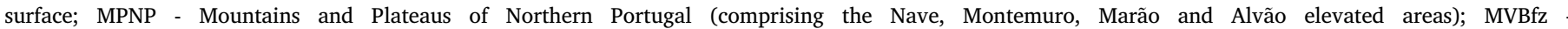
Manteigas-Vilariça-Bragança fault zone; PRVfz - Penacova-Régua-Verín fault zone. The inset indicates the study area. 
Alonso-Zarza et al., 2002; Alonso-Gavilán et al., 2004; de Vicente et al., 2018; Cunha et al., 2019). The topmost unit of the sedimentary infill consists of relatively thin, but extensive, alluvial-fan ochre deposits ("Rañas") connected to fluvial deposits that are considered to be Late Pliocene-Early Pleistocene in age, recording the establishment of exhoreic drainage and pre-dating the period of fluvial incision related with terrace formation (e.g., Pérez-González and Gallardo, 1987; Martín Serrano, 1988, 1991, 1994; Gutierrez Elorza et al., 2002; Pereira et al., 2015). The Douro has a maximum of 14 terraces below the alluvial-fan ochre deposits (Rañas) within the Cenozoic Douro Basin, positioned between $+141-144 \mathrm{~m}$ (highest and oldest) and $+8-10 \mathrm{~m}$ (lowest and youngest) Pérez-González, 1982Based on a height-age transfer function, Silva et al. (2017) obtained an age of 2.3 Ma for the general valley downcutting in central Spain for basins draining to the Atlantic. In western and central Iberia, paleoclimate was mainly hot and dry during the Paleogene-Zanclean, but was humid during the late Zanclean-Gelasian (e.g., Barrón et al., 2010; Pais et al., 2012).

The study area comprises the western margin of the Douro Cenozoic Basin. Here, remains of a thin sedimentary cover over the Variscan basement documents Paleogene-Zanclean alluvial/fluvial units that collectively record (1) drainage routed towards the east (to the endorheic Douro Cenozoic Basin) and (2) a culminant unit of the sedimentary infill (Late Pliocene to early Pleistocene), only locally preserved, that records the ancestral Douro River flowing towards the west (to the Atlantic coast) (Martín Serrano, 1991, 1994; Pereira et al., 2000). In the area around Régua, Ferreira $(1971,1978)$ identified two high fluvial erosion levels at $650-600 \mathrm{~m}$ and 500-450 $\mathrm{m}$ a.s.l. (named 'high Atlantic Douro' River levels) that are inset into the regional planation surface. The younger, inset high-level surface remnants correspond to a large fluvial valley, with localized occurrences of fluvial sedimentary deposits preserved within the Mirandela area (Fig. 3). Most of the downstream reaches of the Lower Douro show a form of the ancestral Douro valley, also with localized sedimentary deposits, such as at Porto (122 m a.s.l.; +120 m; Araújo et al., 2003) and Gondomar $(136 \mathrm{~m}$ a.s.l.; $+136 \mathrm{~m}$ ) (Figs. 1 and 3). These ancestral relicts of Atlantic drainage are considered to span $\sim 3.7-1.8 \mathrm{Ma}$ (allostratigraphic unit UBS13; Cunha, 1992a,b, 2019), based mainly on palynology and stratigraphical/geomorphological correlation (Costa and Teixeira, 1957; Teixeira et al., 1962; Cachão, 1990; Pereira, 1997; Pais et al., 2012). A major climate change ocurred at ca. 3.7 Ma, from the generally dry and hot climates prior to the Zanclean (Lower Pliocene) to the humid and hot climate during the latest Zanclean to Piacenzian. This major change is supported by studies of paleontology (Vieira et al., 2011, 2018; Silva et al., 2010) and sedimentology (Cunha, 1992a, 2000; Cunha et al., 1993; Pais et al., 2012) studies. The warm-humid climate during 3.7-2.8 Ma was followed by progressive cooling (Vieira et al., 2018). In summary, the ancestral Douro was identified in the study area to be routed towards the Atlantic Ocean, probably between $\sim 3.7$ and $2 \mathrm{Ma}$, when sea level reached a maximum of about $+20-40 \mathrm{~m}$ (e.g. Miller et al., 2005), the climate was humid and hot, and the regional uplift rate was moderate (Cabral, 2012). Due to its culminant position within the fluvial landscape, where it is represented as a wide valley-floor surface at the top of the younger entrenched fluvial strath terrace sequence, this sedimentary unit/geomorphic reference-level thus predates the period of enhanced fluvial incision.

The different stages of drainage evolution lie in an area crossed by NNE-SSW-oriented late Variscan fault zones. These structures were reactivated during the late Cenozoic as left-lateral strike-slip deformation zones (e.g., de Vicente et al., 2008, 2011, 2018; Cunha et al., 2019). In the Manteigas-Vilariça-Bragança fault zone, the small Vilariça and Longroiva tectonic basins were developed (Cabral, 1989; Cabral, 1995; Pereira and Azevedo, 1995). Although tectonic structures exist within the study area, the uplift rate during the last $\sim 3 \mathrm{Ma}$ is considered to have been low to moderate at most. As such, the landscape only shows localized adjustments in proximity to the major tectonic structures with little impact upon regional slope.

\section{Materials and methods}

The information presented here is derived from geomorphological, tectonic, stratigraphical, sedimentological and chronological data using a standard approach for fluvial landscape development studies (e.g. Stokes et al., 2012). Firstly, a geomorphological study of the broader region was undertaken to characterize the major fluvial surface units. This used an integrated approach of satellite remote sensing and Digital Elevation Model (DEM) analysis within GIS. The regional analysis was supplemented by more detailed remote sensing/DEM interpretation and identification of surfaces and terraces in areas critical to the understanding of drainage evolution. Secondly, river terrace levels were differentiated on the basis of (1) relative height, (2) lithostratigraphic and sedimentological characterization of the deposits and (3) luminescence dating of the terrace sediments. Collectivelty, these enabled quantification of the timing of fluvial aggradation and incision episodes.

Geomorphological mapping was undertaken in three stages: (1) analysis of satellite imagery of Landsat 7 and 8 (true colors), 1/25,000 black/white aerial photographs and two Digital Elevation Models, one based upon a 1/25,000 topographic database and another based on the ALOS data (https://www.eorc.jaxa.jp/ALOS/en/aw3d30/index.htm), informed by the DEM recommendations of Boulton and Stokes (2018); (2) production within GIS of geomorphological and fault-pattern maps; (3) field ground-truthing, using topographical $(1 / 25,000)$ and geological $(1 / 50,000)$ base maps.

Fieldwork included detailed geomorphological mapping, identification of probable active faults, stratigraphic logging and sedimentological characterization of fluvial deposits in order to obtain data on the depositional facies and the sedimentary processes and depositional environments they represent. This included sediment colour, texture, maximum particle size, clast lithology, fossil content, bedding and its overall depositional architecture.

For optically stimulated luminescence (OSL) dating, thirteen samples were collected from outcrops of river-terrace sedimentary units within the study area. The OSL dating technique, in terms of laboratory material preparation, measurement and age modelling, is described in full within the Supplementary Information. However, only the three lowest terraces, which record the more recent episodes of Douro River incision, had sand deposits suitable for sampling. The strategy involved targeting units from the base to the top of a given terrace level, in order to provide the timing of aggradation (e.g., Cunha et al., 2017). However, in some terrace deposits the target sands were rare or absent. Sampling tubes were hammered into previously cleaned outcrops. Immediately adjacent to each tube, a sub-sample of sediment was collected for determination of field water content, saturation water content and dose rate, all of which are required for the final age modelling.

\section{Results}

\subsection{Old landform levels}

In the study area (Fig. 4), several landform levels occur: (1) the North Iberian Meseta planation surface, (2) the Mountains and Plateaus of Northern Portugal, (3) some highly resistant quartzite uplands, (4) large depressions developed in less resistant metamorphic rocks, (5) remnants of low-resistance Cenozoic sedimentary cover, (6) high-level records of early Douro drainage, routed to the Atlantic, and (7) the entrenched lower part of the Douro valley, with river-terrace staircases.

The regional landscape is dominated by an extensive planation surface, with a slight regional slope towards the east. This surface is well preserved in granite basement but deeply dissected in less resistant metamorphic basement (Ferreira, 1971, 1978, 1980, 1991). The planation surface was generated during Cretaceous to late Miocene times, providing the sediments for the progressive infilling of the Douro Cenozoic Basin (to the east). Since the middle Tortonian ( $9.6 \mathrm{Ma}$; 


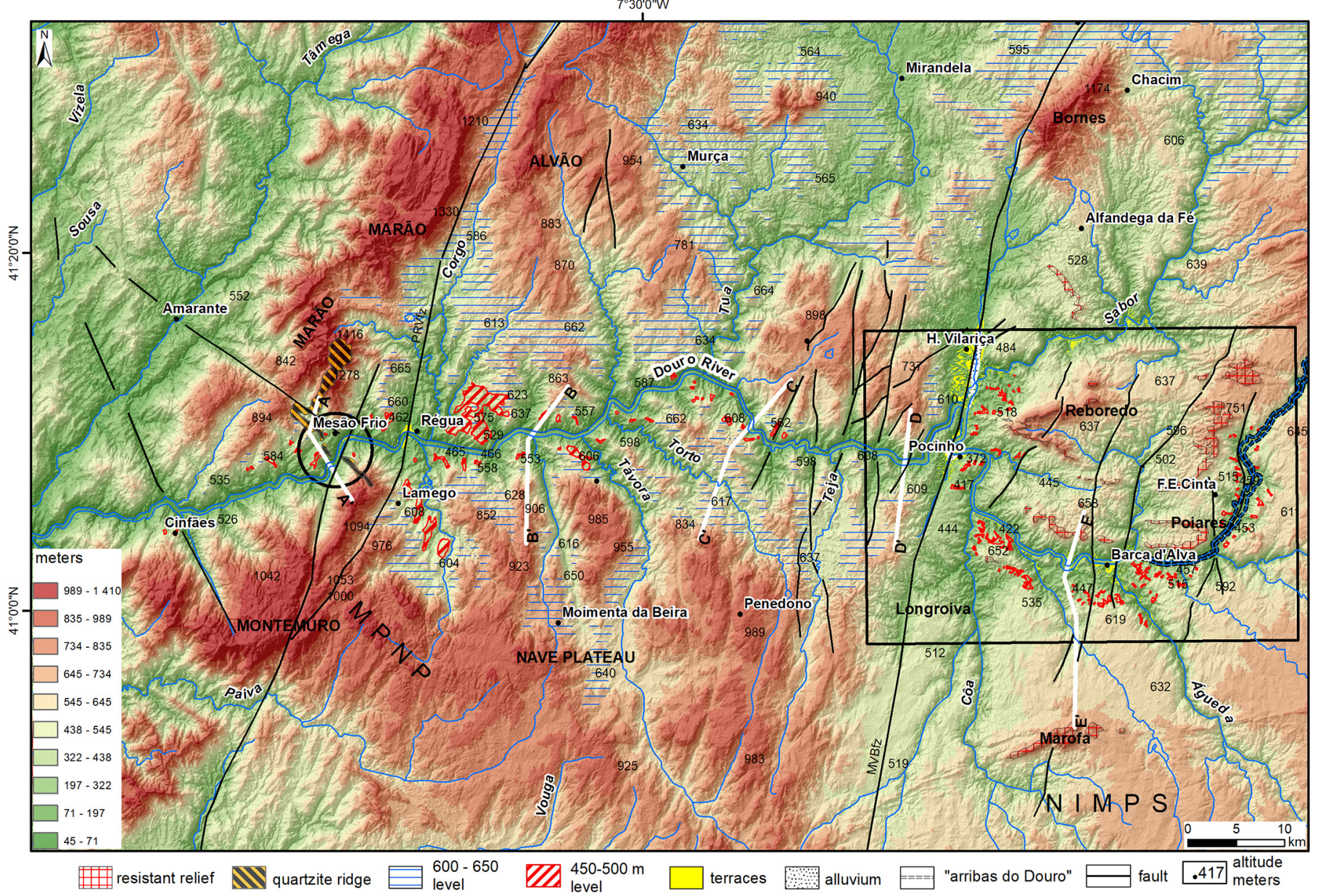

Fig. 4. DEM showing the hypsometry of the study area. It can be seen that the North Iberian Meseta planation surface (NIMPS) to the east of the MVBfz is tilted westwards (at $700 \mathrm{~m}$ to $500 \mathrm{~m}$ a.s.l.), but the planation surface rises westwards by tectonic steps up to $700-1000 \mathrm{~m}$ a.s.l. in the MPNP. A very wide fluvial level, at $600-650 \mathrm{~m}$ a.s.l., is represented. There are remnants of the large valley of the ancestral Douro at $\sim 450-500 \mathrm{~m}$ a.s.l. The entrenched Douro valley exhibits incised meanders and reaches that were controlled by faults. The black circle indicates crossing (at Mesão Frio), by the Douro, of the Montemuro-Marão upland. The inset indicates the area shown in Fig. 6. A-A' to E-E' are topographic profiles of which are shown in Fig. 5.

Pereira, 1997; Cunha and Pereira, 2000; Cunha et al., 2000, 2019; Feio and Daveau, 2004; Pais et al., 2012), fault controlled differential uplift has segmented this planation surface. East of the Manteigas-Vilariça-Bragança fault zone (MVBfz), the planation surface is tilted from $\sim 750 \mathrm{~m}$ a.s.l. (in the east; Miranda do Douro) to $500 \mathrm{~m}$ (in the west; at Vilariça and Longroiva tectonic depressions). In this sector the surface is referred to as the North Iberian Meseta planation surface (NIMPS). Between the Manteigas-Vilariça-Bragança and the Penacova-Régua-Vérin fault zones, the planation surface is located at between $657 \mathrm{~m}$ a.s.l. (in the east) and $700-1000 \mathrm{~m}$ a.s.l. (in the west), and is referred to as the Mountains and Plateaus of Northern Portugal (MPNP) (Figs. 3 and 4). The approximate NNE-SSW trend of the Montemuro and Marão mountain uplands formed a divide between the former easterly (towards the endorheic Douro Cenozoic Basin) and westerly (to the Atlantic Mondego Cenozoic Basin) routed drainage.

Resistant ridges, mainly comprising Ordovician quartzites, stand out above the regionally extensive plateaus developed on the less resistant metamorphic basement (Fig. 4). Examples are the Mount Reboredo (966 m a.s.l.), situated east of the Vilariça depression, the Poiares ridges (711 m a.s.l.), north of the Douro valley in the Barca d'Alva sector, and the Mount Marofa ( $976 \mathrm{~m}$ a.s.1.), at south of the Douro River and rising to $\sim 280 \mathrm{~m}$ above the surrounding plateaus (NIMPS).

In the study area, several small remnants of Cenozoic sedimentary cover overlying the Variscan basement are preserved within and around the Vilariça and Longroiva tectonic depressions. During the late
Cenozoic, these small strike-slip tectonic basins were subjected to asymmetric subsidence, as evidenced by the eastward tilt of the Palaeogene to Miocene sequences (Cabral, 1989; Pereira and Azevedo, 1995; Cunha and Pereira, 2000) and by the preferential development of fluvial terraces on their western side.

The two highest Douro River levels, which are inset into the regional planation surface, were originally identified by Ferreira (1971, 1978) in the area around Régua at $650-600 \mathrm{~m}$ a.s.l. and 500-450 m. Our new mapping has extended the distribution of these highest Douro River levels over a much larger area (Figs. 3, 4 and 5). Both fluvial levels are discontinuous in the landscape due to erosion and display undulating surface expressions related to lithological contacts and/or tectonic displacement. In the study area, the first inset level ocurs at 650-580 $\mathrm{m}$ a.s.l. and comprises a broad fluvial surface developed over a large ENE-WSW-oriented depression. The second high level (Fig. 1C $\log$ profile 2) forms a discontinuous occurrence along the Douro valley margins, between 575 and $400 \mathrm{~m}$ a.s.l., being lower as $365 \mathrm{~m}$ a.s.l. at the Vilariça tectonic depression (Figs. 4 and 5). It corresponds to a wide fluvial valley-floor (up to $\sim 5 \mathrm{~km}$ width). This surface does not occur in areas of higher topography west of the Manteigas-Vilariça-Bragança fault zone or where residual uplands occur. For example, it disappears where the high topography of the Carrazeda de Ansiães is traversed, downstream of the small Vilariça basin, and in the Cinfães-Lamego reach, where the Marão-Montemuro mountains are crossed (Figs. 3 and 4). East of the Manteigas-Vilariça-Bragança fault zone, this level is 

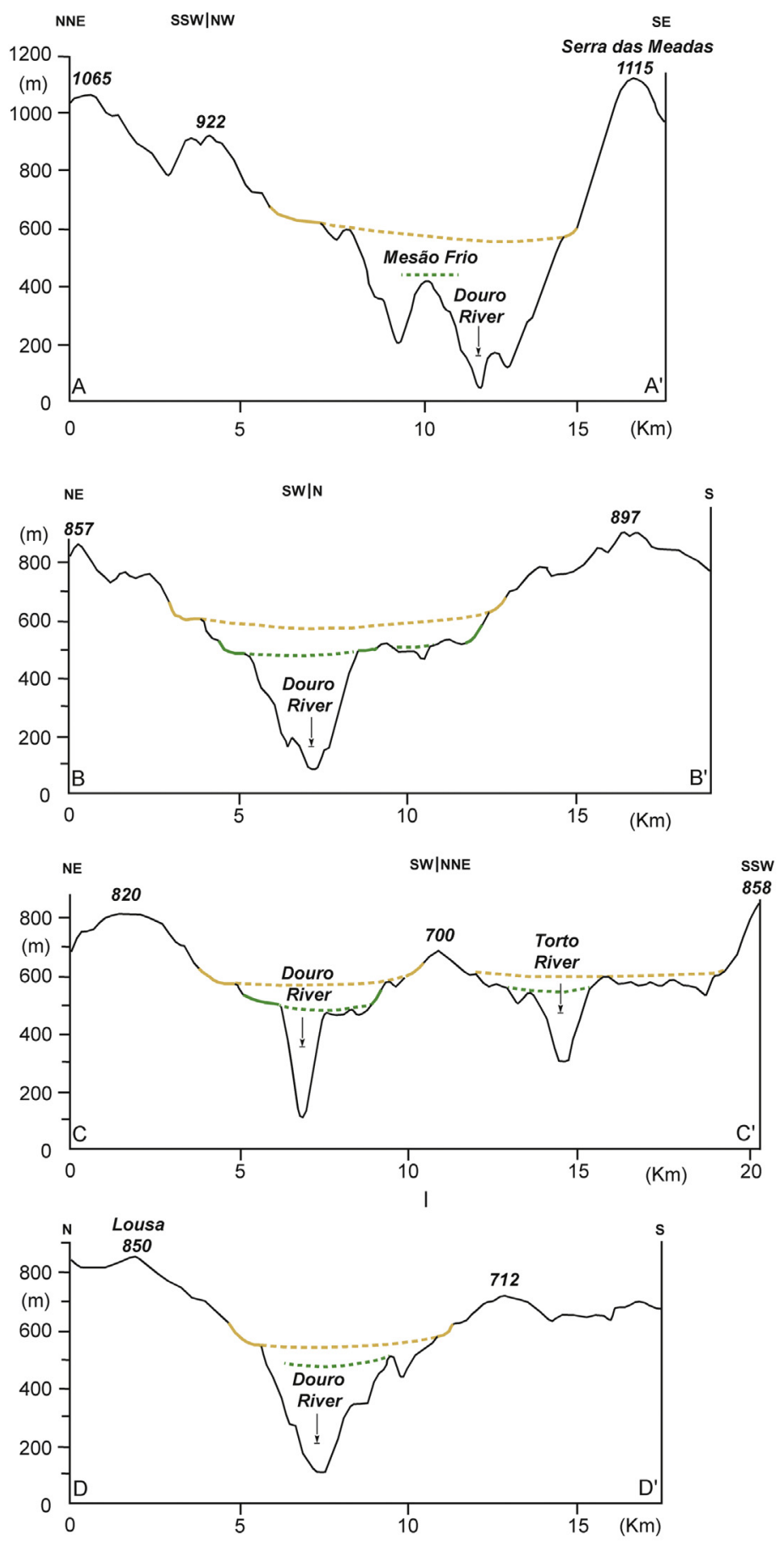

NNE $\quad$ SSW|N

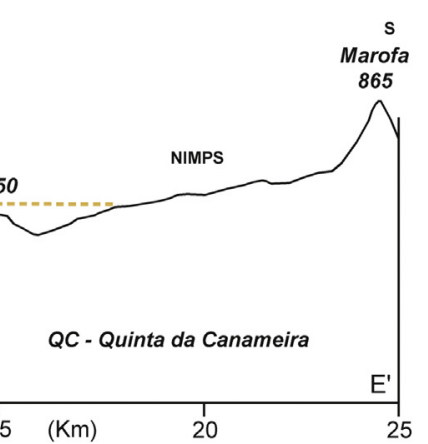

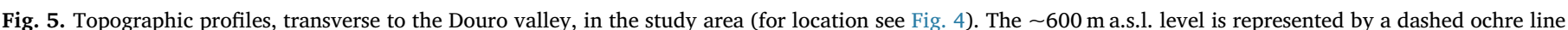

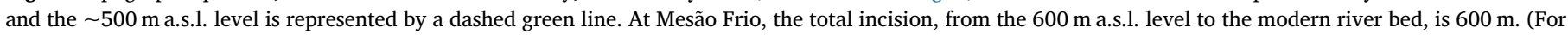
interpretation of the references to colour in this figure legend, the reader is referred to the web version of this article.) 


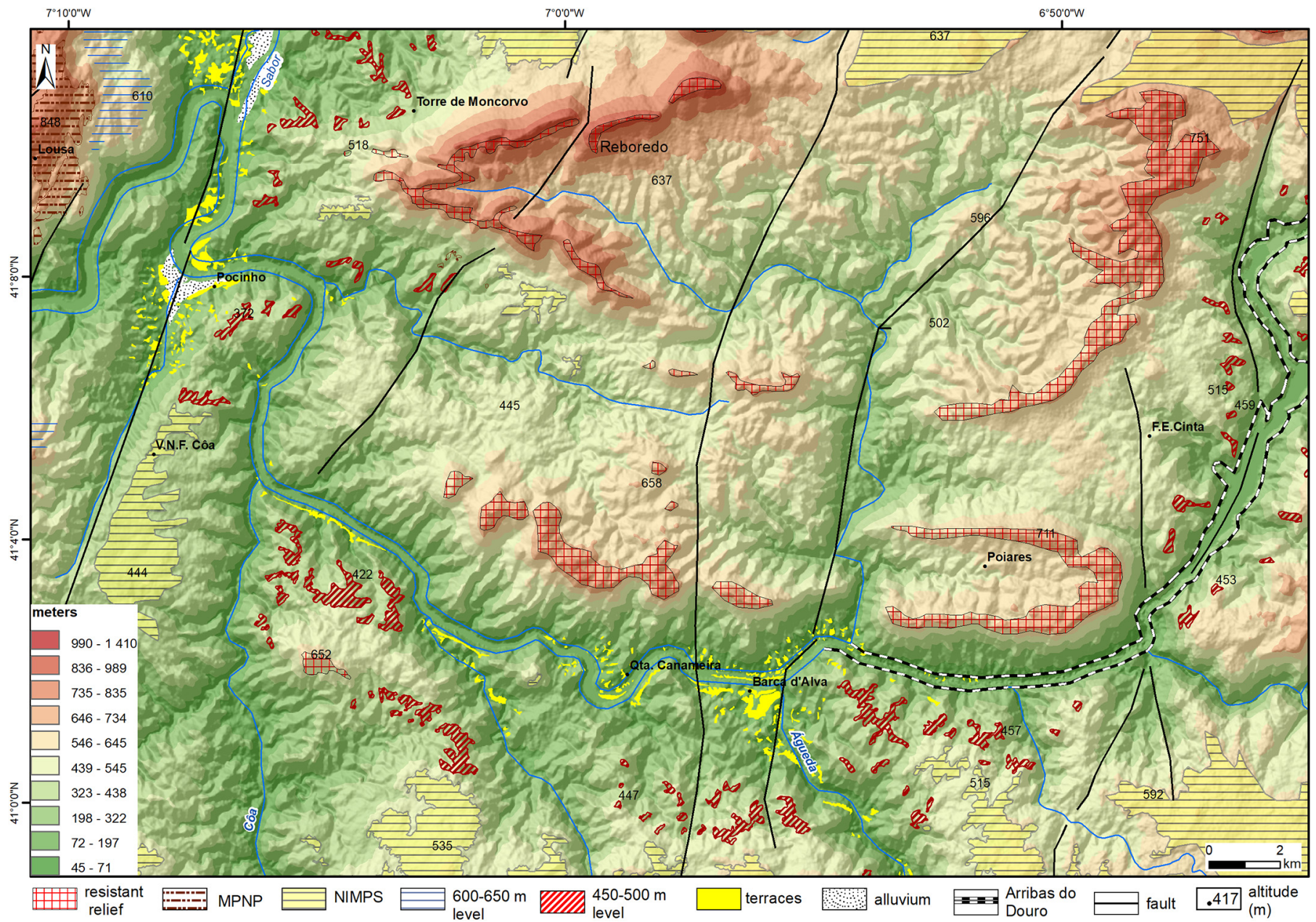

Fig. 6. Geomorphological map of the main terrace remains along the Douro valley, in the Freixo de Espada à Cinta - Vila Nova de Foz Côa area.

developed at a slightly lower altitude, namely $365 \mathrm{~m}$ a.s.l. at Pocinho, $455 \mathrm{~m}$ a.s.l. at Barca D'Alva and $515 \mathrm{~m}$ a.s.l. at Freixo de Espada à Cinta. This fluvial level is not represented further upstream until Zamora (Fig. 1). The narrow and entrenched parts of the valleys associated with incision by the Douro and its tributaries are located at lower levels than the remnants of this wide ancestral valley-floor.

\subsection{River terrace staircases}

\subsubsection{Geomorphological characterization of the strath levels}

In the Lower Douro, staircases of strath terraces are developed in sectors associated with (1) tectonic depressions, (2) less resistant lithologies (e.g. Cenozoic deposits) or (3) along the convex banks of enlarged meanders. The river has developed terraces of considerable extent within the Vilariça and Barca d'Alva reaches and on the inner convex side of the Quinta da Canameira valley meander (Figs. 6 and 7). Within the Quinta da Canameira meander, lateral migration caused fluvial sediments to be accumulated on the inside bank. Another location favourable for fluvial aggradation and terrace formation occurs near an unusual junction of the Sabor tributary with the Douro. Here, the Sabor flows in a direction opposite to the trunk river, promoting damming conditions near its mouth, locally known as Rebofa and especially intense during high floods. In addition, the marked narrowing of the Douro valley immediately downstream of the Sabor confluence, where it begins to incise into granite basement, creates natural damming conditions in this gorge reach, promoting aggradation and fill-terrace formation in the vicinity of the Sabor confluence. This confluence occurs within the elongated Vilariça tectonic depression, further highlighting this sector as favourable for terrace formation.

In the reaches of the Douro valley, located between Barca d'Alva and Foz do Sabor (Fig. 6), up to nine strath terrace levels occur below the 455-365 m a.s.l. level. They are termed T1 to T9 (from the lower to the higher). The substantial lateral upstream-downstream extent of the T1 to the T6 straths means they are easily correlated. Terrace level assignment and correlation becomes challenging above the T6 level because preservation is poorer. Terrace T9 reaches up $+246 \mathrm{~m}$ at Barca d'Alva and $+220 \mathrm{~m}$ at Pocinho, within the Vilariça strike-slip basin (Table 1). The vertical spacing between the strath levels varies from $\sim 15$ to $25 \mathrm{~m}$ (average $20 \mathrm{~m}$ ) for the levels below T7, whereas for the two higher T8 and T9 straths the vertical separations are larger (35-60 m). Strath levels below T6 are subparallel to the modern river bed, while T7, T8, T9 and the ancestral Douro valley-floor surface (the 455-365 m a.s.l. level) are steeper in the Quinta da Canameira and Barca d'Alva areas than their equivalents in the Pocinho area (Table 1; Figs. 8, 9, 10 and 11), i.e. showing a diverging upstream pattern.

The T1, T2 and T3 strath terraces have sediment thicknesses of up to $11 \mathrm{~m}$. In contrast, T4 to T9 consist of erosional bedrock surfaces, some of them with only a thin cover of gravel (with boulders and cobbles). The best preserved and most visible terrace along the Douro valley is T3 $(\sim+50 \mathrm{~m}$ a.r.b.). There is an equivalent of this terrace along the Sabor tributary, extending from the confluence with the Douro for $>30 \mathrm{~km}$ upstream (Martins et al., 2018). The extensive spatial development and sedimentary thickness of T3 contrasts with the lower and younger bedrock terraces, which have much less expression in the landscape.

The Quaternary deposits of the studied Lower Douro reach show different sedimentary characteristics (Table 2). 

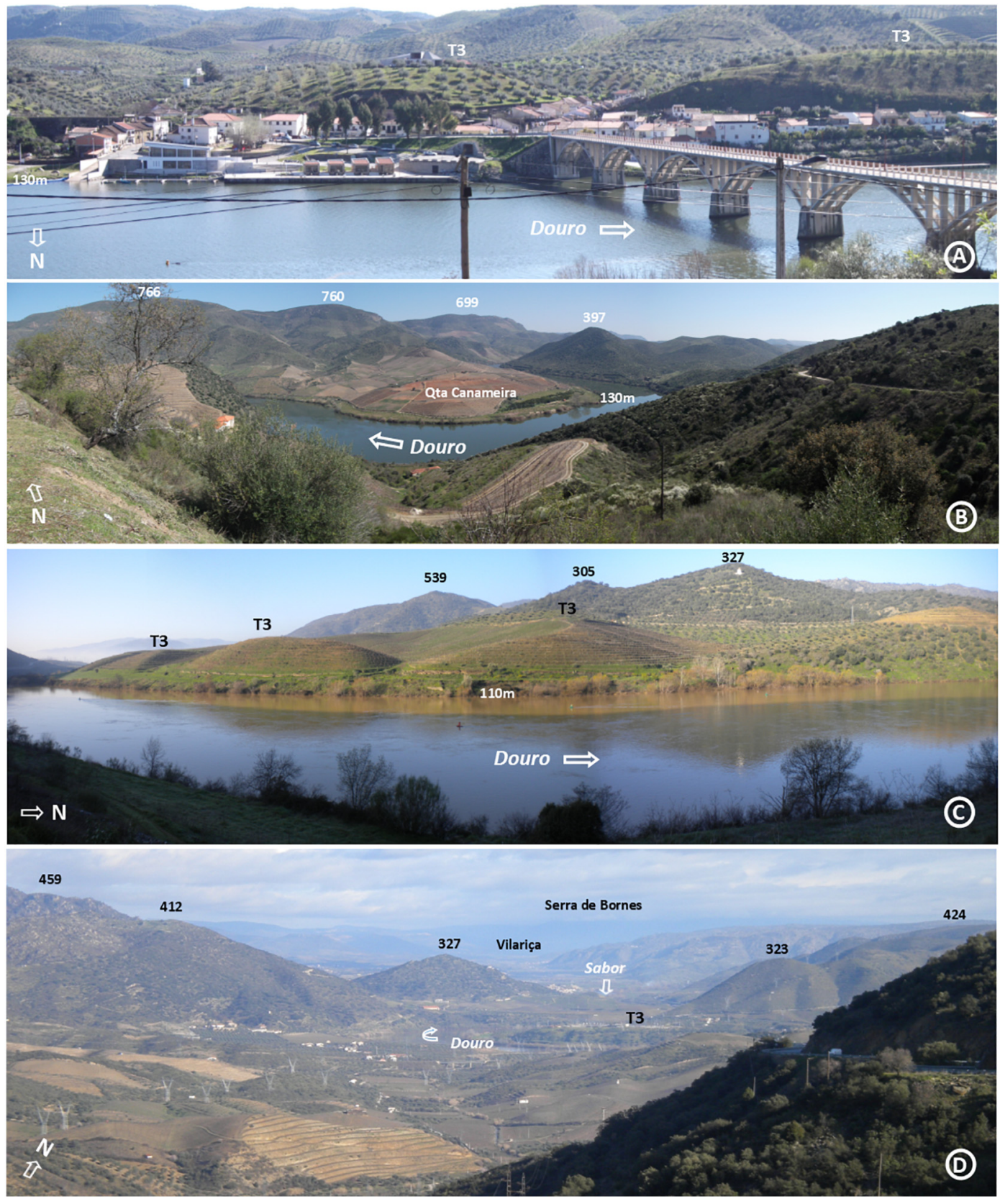

Fig. 7. A - Panoramic view, from the north, of the southern flank of the Douro valley at Barca D'Alva. The T3 terrace, on the left-hand side of the valley, can be seen. B - The Quinta da Canameira terrace staircase (Douro right bank) and the Poiares syncline (southern flank) quartzite ridges at the top. C - The Douro valley, Quinta do Vale Meão terrace staircase (left bank). D - Northwards view of the Douro valley near Pocinho; the Vilariça tectonic depression is the flat lowland in the background.

\subsubsection{Luminescence ages of the strath terrace deposits}

Only the three lower terraces have sufficient sediment thickness and suitable materials to be used for OSL dating. The OSL technique revealed ages of between $>360-230 \mathrm{ka}$ and $13 \mathrm{ka}$ (Tables 3 and 4). The samples from $\mathrm{T} 3$ have $\mathrm{D}_{\mathrm{e}}$ values lying above $2 \mathrm{xD}_{0}$ (corresponding to $86 \%$ of luminescence saturation). In light of the possibility of small systematic errors during measurement of the luminescence signal, we adopted the approach of Wintle and Murray (2006) of only presenting minimum doses (equivalent to $2 \mathrm{xD}_{0}$ ), and thus minimum ages.

The T1 terrace was dated (Qz-OSL) using samples collected from a trench opened at Quinta do Vale Meão (Pocinho) that exposed silty sands: $102211(25.2 \pm 1.3 \mathrm{ka})$ was collected at $\sim 1 \mathrm{~m}$ above the base of the $\mathrm{T} 1$ sediments, $102212(17.0 \pm 1.0 \mathrm{ka})$ at a middle position and $102219(16.7 \pm 1.0 \mathrm{ka})$ near the top. The T1 deposits were also dated from two samples collected from the topmost deposits at Cortes da
Veiga (Pocinho): $102220(14.8 \pm 1.0 \mathrm{ka})$ and $102218(12.9 \pm 0.8 \mathrm{ka})$. An aeolian brown coarse silty level covering the T3 terrace at Barca d'Alva (Douro left bank: $+65 \mathrm{~m}$ a.r.b.) was dated $31 \pm 2 \mathrm{ka}$ (sample 102214). Previously, in another trench at the Vale Meão site, five fluvial sand samples provided OSL ages in the range 17-14 ka and the colluvium at the top was dated 14-12 ka, while an alluvial sequence with its surface at $120 \mathrm{~m}$ a.s.l. (T1) at Vilariça was dated $39-18 \mathrm{ka}$ (Rockwell et al., 2009). In summary, the aggradation of T1 sediments represents the age range $39-12 \mathrm{ka}$.

Sample 102217, collected from a sand lense in the T2 gravel deposits at Ribeira da Barca (Pocinho), yielded an age of $57 \pm 4 \mathrm{ka}$ (Quartz-OSL). The age obtained by the pIRIR protocol ( $98 \pm 7 \mathrm{ka}$ ) was considered to be an overestimate due to partial bleaching. Since the sample was collected from the basal deposits it is likely that the T2 aggradation in this area spanned $\sim 60-50 \mathrm{ka}$. 
Table 1

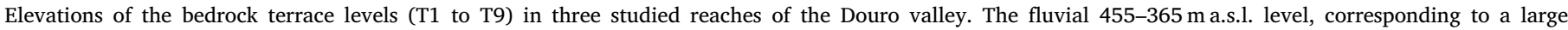
paleovalley, is here interpreted as the valley of the ancestral Douro River (ADR) (Atlantic drainage).

\begin{tabular}{|c|c|c|c|c|c|c|}
\hline \multirow[t]{2}{*}{ Geomorphic references } & \multicolumn{2}{|l|}{ Pocinho } & \multicolumn{2}{|c|}{ Qta. da Canameira } & \multicolumn{2}{|l|}{ Barca D'Alva } \\
\hline & Altitude (m) & Elevation a.r.b (m) & Altitude (m) & Elevation a.r.b (m) & Altitude (m) & Elevation a.r.b (m) \\
\hline High and large paleovalley (ADR) & 365 & +262 & 450 & +334 & 455 & +337 \\
\hline T9 & 323 & +220 & - & - & 364 & +246 \\
\hline $\mathrm{T} 8$ & 289 & +186 & 319 & +203 & 320 & +202 \\
\hline $\mathrm{T} 7$ & 229 & +126 & 273 & +157 & 291 & +173 \\
\hline T6 & 209 & +106 & 227 & +111 & 240 & +122 \\
\hline T5 & 195 & +92 & 207 & +91 & 210 & +92 \\
\hline $\mathrm{T} 4$ & 179 & +76 & 186 & +70 & 190 & +72 \\
\hline $\mathrm{T} 3$ & 151 & +48 & 168 & +52 & 171 & +53 \\
\hline $\mathrm{T} 2$ & 134 & +32 & 150 & +34 & 145 & +27 \\
\hline $\mathrm{T} 1$ & 116 & +13 & 132 & +16 & 135 & +17 \\
\hline Modern river bed & 103 & 0 & 116 & 0 & 118 & 0 \\
\hline
\end{tabular}

The T3 level was dated using the pIRIR protocol, since the QuartzOSL signal was found to be saturated for all samples. Several minimum ages were obtained: 112233 ( $>360 \mathrm{ka}$ ), from the basal T3 sediments at Barca d'Alva; 102215 (> $230 \mathrm{ka}$ ) and 102216 (> $290 \mathrm{ka}$ ), from the basal T3 deposits at Pocinho; and 102213 (> $270 \mathrm{ka}$ ), from the middle of the T3 depositional sequence at Barca d'Alva. Thus, the T3 sediment aggradation probably occurred between $\sim 370$ and $220 \mathrm{ka}$. It is interesting to note that Acheulian (Lower Paleolithic) artefacts were collected from the T3 terrace at Quinta do Vale Meão and also from a correlative Côa River terrace, located at $+40 \mathrm{~m}$ a.r.b., at Penascosa (Zilhão, 1997). In central Portugal (River Tejo/Tagus), Acheulian industries associated with river-terrace deposits were recently dated to between $\sim 360$ and $200 \mathrm{ka}$ (Cunha et al., 2017).

\subsection{Tectonic activity}

Field surveys allowed the identification of several faults affecting terrace deposits. At Quinta do Vale Meão, a fault ( $\left.220^{\circ} \mathrm{E}, 80^{\circ} \mathrm{NW}\right)$ marks the contact between granite, to the west, and T3 deposits (sandy matrix-supported gravels) to the east (Cabral, 1989, 1995). Given the vertical offset of $\sim 20 \mathrm{~m}$, and assuming a probable age of $\sim 220 \mathrm{ka}$ for the uppermost terrace deposits, an average slip rate for the vertical component of this fault can be estimated as $\sim 0.09 \mathrm{~m} / \mathrm{ka}$. This location corresponds to the Vilariça fault, which delimits the eastern side of the minor Vilariça strike-slip tectonic basin (Figs. 9 and 10). Paleoseismic studies have shown $\mathrm{T} 1$ to have been displaced by the Vilariça fault (Rockwell et al., 2009; Cabral et al., 2010; Perea et al., 2010; Vilanova et al., 2014).

\subsection{Fluvial incision and quantification of crustal uplift}

The height of a fluvial terrace surface above the modern river profile (assuming negligible surface erosion) can be used to calculate the longterm fluvial incision rate, which an in turn be used as aproxy for crustal uplift (Bridgland, 2000; Maddy et al., 2000), albeit taking into account the uncertainty that the river might not have fully achieved a steadystate longitudinal profile following the uplift.

Fluvial incision in the study area can be estimated using different geomorphic markers: (i) the North Iberian Meseta planation surface, (ii) the 455-365 m a.s.l. level (the ancestral Douro valley-floor) and (iii) the OSL-dated T1, T2 and T3 levels. Using the NIMPS as the oldest surface marker, we can estimate the differential uplift that has occurred since $\sim 9.6 \mathrm{Ma}$ (the beginning of relief differentiation; Pais et al., 2012). Faults have segmented this planation surface into several plateaus (Figs. 4, 6, 12 and 14). Using the long-term incision rate, immediately east of the Vilariça Fault (Pocinho - Barca d'Alva) the remnants are at 500-555 m a.s.l. ( $+367-+439 \mathrm{~m}$ a.r.b.), giving an incision rate of $0.04-0.05 \mathrm{~m} / \mathrm{ka}$. Immediately west of the Vilariça Fault, the corresponding remnants are at $607 \mathrm{~m}-845 \mathrm{~m}$ a.s.l. (+505-+743 $\mathrm{m}$ a.r.b.), giving an incision rate of $0.05-0.08 \mathrm{~m} / \mathrm{ka}$.

Using the ancestral Douro valley surface (the 575-365 $\mathrm{m}$ a.s.l. level) as a geomorphic reference (Figs. 4, 6, 9 and 11) allows estimation of the amount of fluvial incision since $\sim 1.8 \mathrm{Ma}$ (Fig. 13). Immediately east of the Vilariça Fault, within the Pocinho-Barca d'Alva sector, this relict valley surface is at $\sim 364 \mathrm{~m}$ to $455 \mathrm{~m}$ a.s.l. $(\sim+262-+337 \mathrm{~m}$ a.r.b. $)$, providing an incision rate of $\sim 0.15-0.19 \mathrm{~m} / \mathrm{ka}$. West of the Manteigas-Vilariça-Bragança fault zone, until Régua, the relict valley-floor surface is at $475-400 \mathrm{~m}$ a.s.l. ( $+400-+370 \mathrm{~m}$ a.r.b.), giving an incision rate of $\sim 0.22-0.21 \mathrm{~m} / \mathrm{ka}$.

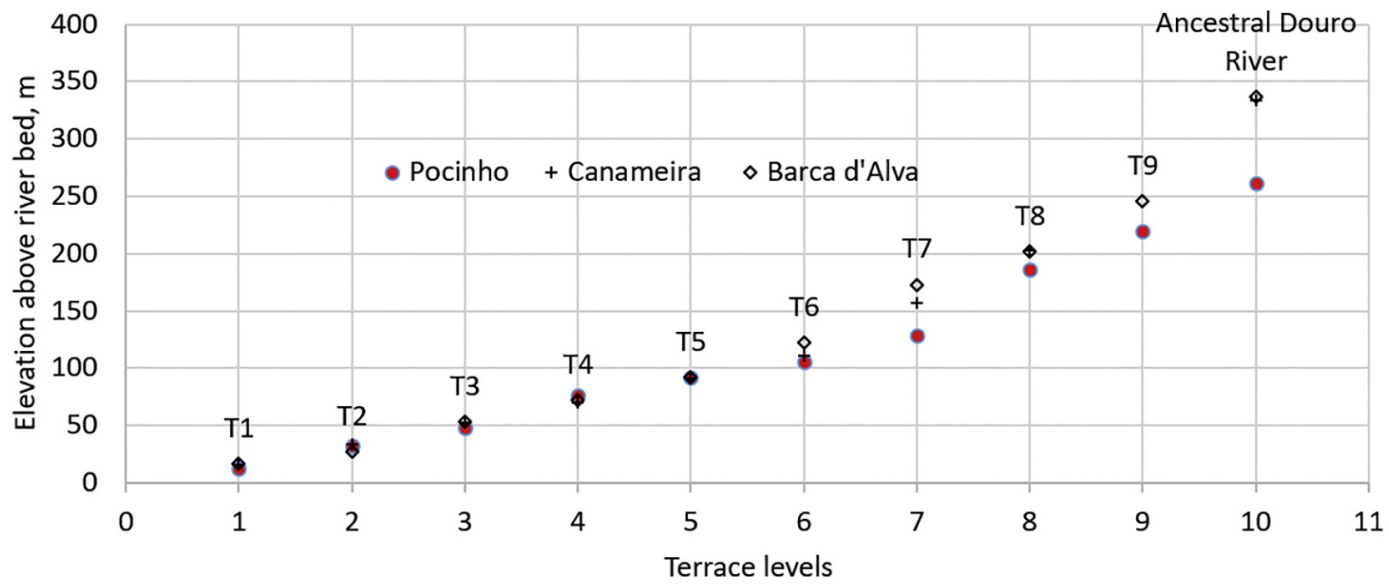

Fig. 8. Projection of the elevation (a.r.b.) of each terrace level, for three studied reaches of the Douro located between Barca d'Alva and Pocinho. 


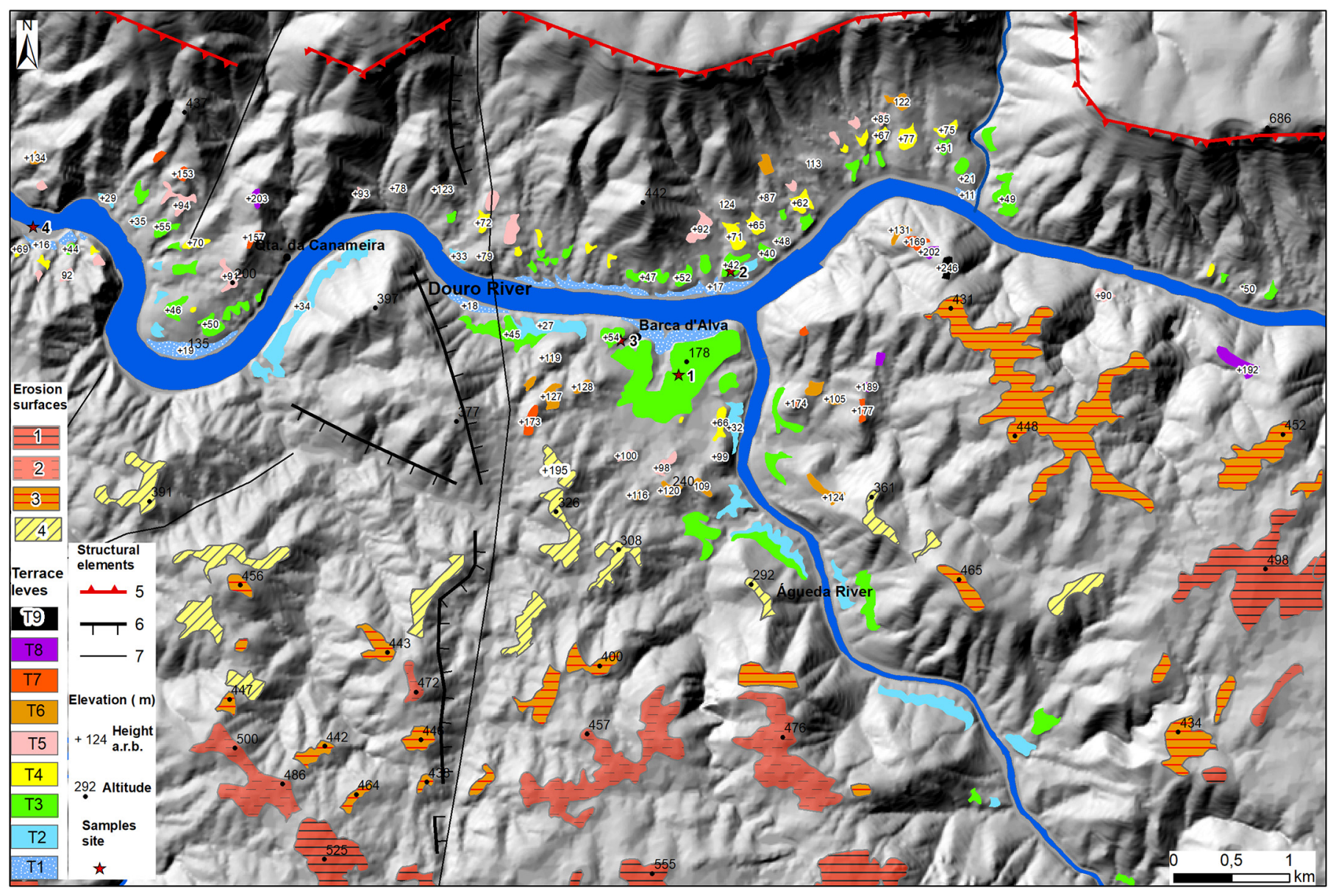

Fig. 9. Geomorphological map of the Barca d'Alva to Quinta da Canameira terrace staircases. 1 - North Iberian Meseta planation surface (NIMPS); 2 - degraded NIMPS; 3 and 4 - fluvial erosion surfaces at 430-465 m a.s.l. probable remnants of the ancestral Douro valley; 5 - scarp of structural relief; 6 - fault scarp; 7 - tectonic lineament; sampled sites (numbered stars): 1 - aeolian cover on T3, left bank (102214); 2 - T3, right bank (102213); 3 - T3, left bank (sample 112233); 4 - modern sample (102234).

The three OSL-dated lower terraces can also provide short-term incision rates, with reference to their terrace surface elevations and ages. Using the T3 level, the incision rate is $\sim 0.21 \mathrm{~m} / \mathrm{ka}$ ( $48 \mathrm{~m} / 230 \mathrm{ka}$ ) for Pocinho and $\sim 0.24 \mathrm{~m} / \mathrm{ka}$ for Barca D'Alva. For T2, the incision rate is $0.44 \mathrm{~m} / \mathrm{ka}(25 \mathrm{~m} / 57 \mathrm{ka})$ for Pocinho and $0.54 \mathrm{~m} / \mathrm{ka}$ for Barca d'Alva. Using T1, the incision rate is $1.40 \mathrm{~m} / \mathrm{ka}(18 \mathrm{~m} / 13 \mathrm{ka})$ for Pocinho and $1.41 \mathrm{~m} / \mathrm{ka}$ for Barca D'Alva; this suggests a progressive increase during the recent Pleistocene.

By plotting the OSL ages derived from sediments forming the uppermost parts of T1-T3, and their elevations a.r.b., the probable ages of the older terraces T4-T9, and of the ancestral Douro valley-floor (ADR), can be extrapolated (Fig. 13).

\section{Discussion}

The transition from the erstwhile internal drainage of the Douro Cenozoic Basin (endorheic stage) to Atlantic Douro River drainage (exorheic stage) has been attributed primarily to antecedence or capture-related headward erosion (e.g., Ferreira, 1978, 1986; Martín Serrano, 1991; Antón et al., 2018; Struth et al., 2019). This transition occurred over a significant time span, encompassing the Pliocene-Pleistocene and reflecting interplay between spatially and temporally variable regional tectonic activity and climatic fluctuation, acting upon a landscape with marked variations in rock strength (e.g. basement versus basin-fill). We first explore these controls very broadly at a continental scale and highlight their potential roles for reorganization of the Douro system. Then we consider these controls more explicitly and explore the evidence from different endorheic and exorheic sectors to interrogate the potential drainage-reorganization mechanisms: antecedence, capture and overspill. Finally, we present a drainageevolution model that documents key stages in the endorheic-exorheic transition, integrating the evidence for controls and mechanisms.

\subsection{Controls on drainage evolution}

Tectonic activity appears to have conditioned the landscape for drainage reorganization, with late Tortonian to Pliocene uplift concentrated around some of the margins (north, east and south) of the Douro Cenozoic Basin (Pyrenean and Iberian orogens, and Central System) (e.g., de Vicente et al., 2011, 2018; Cunha et al., 2019), causing progressive westward tilting and the formation of a regional topographic gradient (Fig. 1). This tectonically induced gradient would have primed the endorheic DCB for drainage re-organisation along its western margin, an area encompassing the present upper reaches of the Lower Douro. Differential uplift and the creation of regional topographic gradients is a commonly cited mechanism for enhancing baselevel lowering and driving headward erosion, leading to capture-related reorganization (e.g. Stokes and Mather, 2003). In the case of the Douro, although uplift caused regional westward tilting, the relative base-level positions between the ancestral system routed to the Atlantic coast (Mondego Cenozoic Basin) and the endorheic DCB remained stable. As such, differential regional uplift would have been of insufficient magnitude to have driven or accelerated headward erosion by the ancestral Atlantic drainage system. 


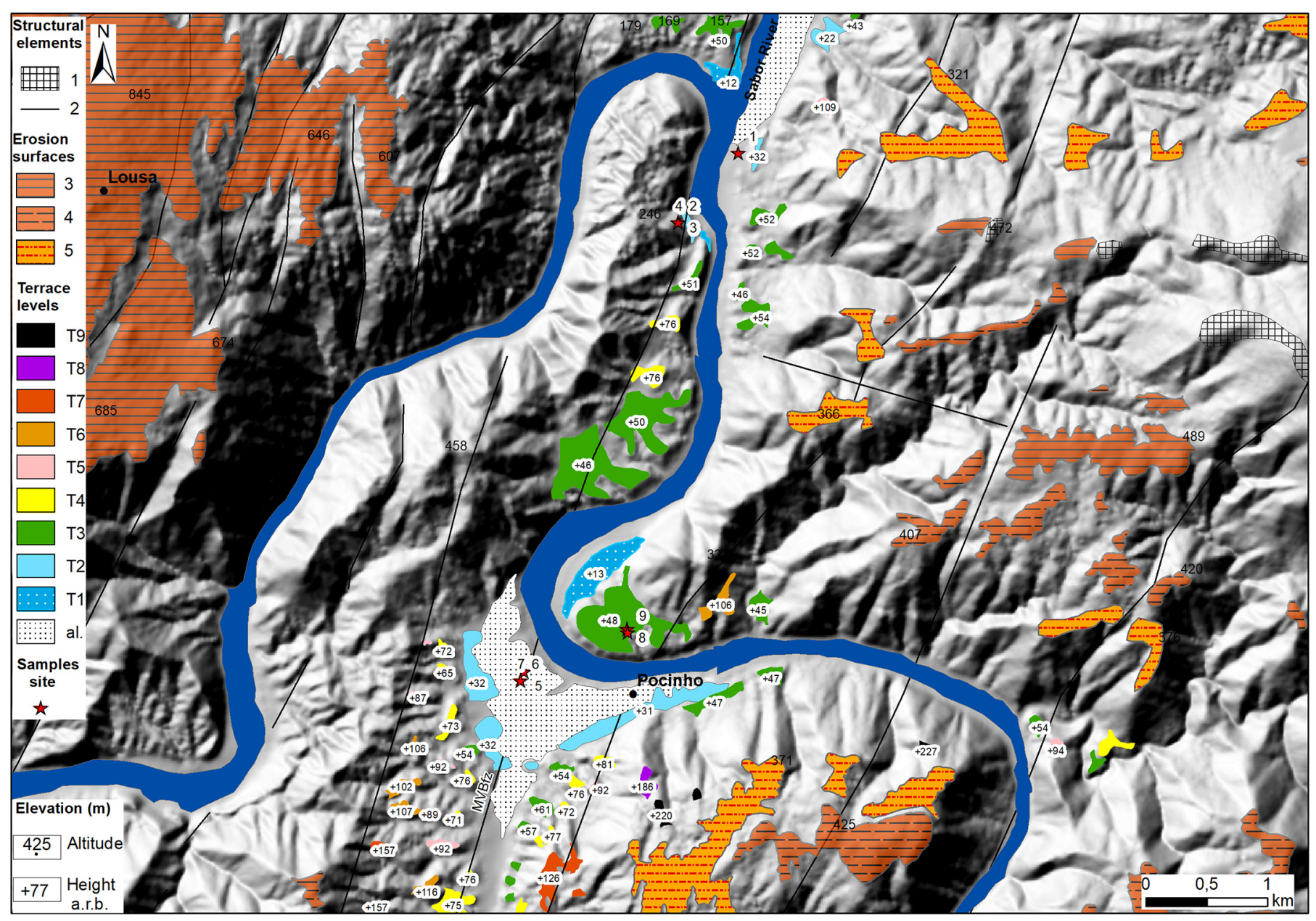

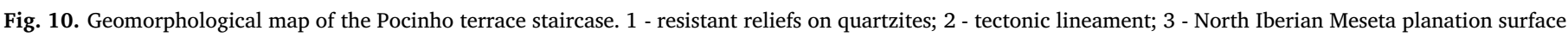

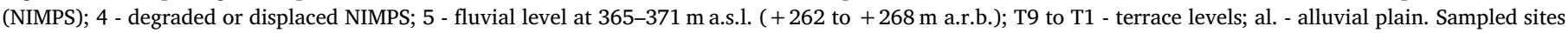

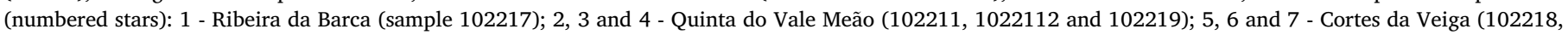
102220 and 102221); 8 and 9 - Pocinho (102215 and 102216).

Climate during the period of drainage reorganization appears to have been hot and humid (early-mid Pliocene), becoming progressively cooler (late Pliocene - Pleistocene). The hot and humid conditions are especially important hydrological factors for the conditioning of a potential drainage reorganization. For example, increased water availability under hot and humid conditions would have resulted in expansion and rising levels of lakes within the endorheic DCB. When combined with the regional westward tectonic tilt, this would have made the western margin of the DCB a potential region for overflow/ spill. Equally, the hot humid climate would have resulted in elevated flood discharges within the ancestral Atlantic drainage system, providing conditions conducive for headward erosion into, and potential capture of, the DCB.

Rock strength is variable throughout the Douro catchment, providing a factor that will either have enhanced or impeded fluvial incision. Higher rock strength is typically associated with the basement, and especially the granite, which dominates the WMDCB region where the reorganization is considered to have occurred. Studies by Struth et al. (2019) of knickpoint-migration rates from the upper reach of the Lower Douro through the WMDCB and up into the DCB during the drainage re-organisation period clearly demonstrate the incision - rock strength suppression and enhancement relationship. However, headward erosion by knickpoint migration requires base-level lowering. This could have been achieved by differential tectonic uplift between the Lower Douro and the DCB but, as previously stated, this was low-negligible, despite the regional westward tilting due to intraplate compression. Eustatic base-level variability can also play a role in fluvial incision and knickpoint migration, for a marine-influenced system with a narrow offshore continental shelf. However, a sustained and large amplitude base level lowering would be required (Bridgland and Westaway, 2012, 2014). Global sea levels during the Pliocene were $\sim 25-40 \mathrm{~m}$ above that at present and subsequently lowered in the Pleistocene as global climate cooled. Thus, eustatic base-level lowering might have some merit as a potential driver of headward erosion but again the occurrence of resistant granite in the upper Lower Douro and the WMDCB (Fig. 1) would have impeded migration, limiting the potential for capture-related reorganization. However, granite can be subject to significant amounts and rates of incision if flood discharges exploit favourable geological discontinuity patterns. Antón et al. (2015) recorded up to $100 \mathrm{~m}$ of fluvial incision and several hundreds of metres of headward erosion, when 'normal' winter floods were re-directed over a natural bedrock spillway during the construction of a dam on a Douro tributary within the WMDCB. This example is in keeping with an overspill process. Interestingly, cosmogenic exposure dating of fluvially eroded straths within bedrock river gorge reaches of the WMDCB by Antón et al. (2012) suggests exceptionally high incision rates within granite, again illustrating the potential for resistant bedrock to be rapidly eroded under favourable conditions.

\subsection{Antecedence, capture or overspill mechanisms?}

For antecedence to have occurred requires a pre-existing drainage 


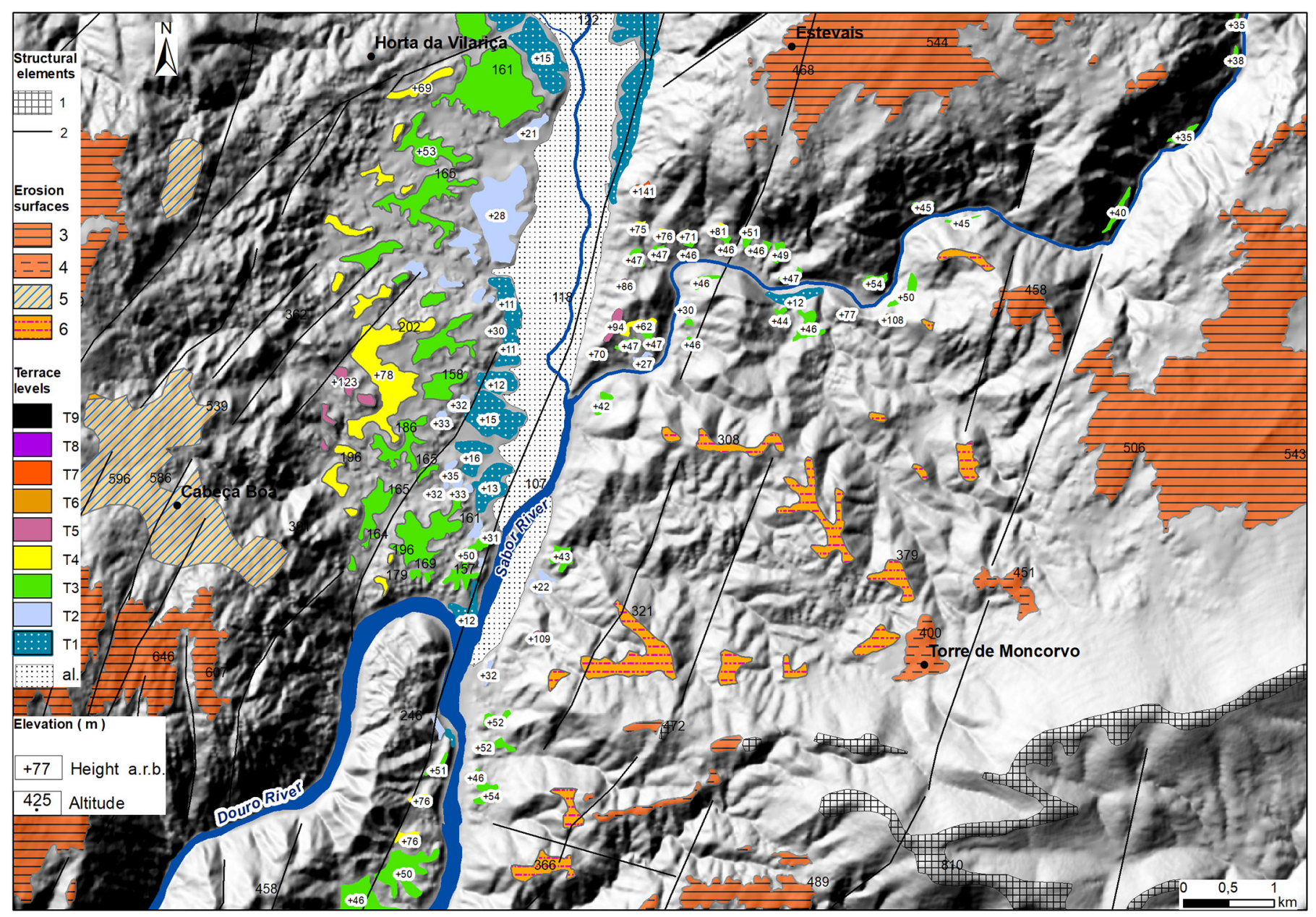

Fig. 11. Geomorphological map of the sector comprising the confluence of the Sabor with the Douro. 1 - residual quartzite upland; 2 - tectonic lineament; 3 - North Iberian Meseta planation surface (NIMPS), displaced by the Manteigas-Vilariça-Bragança fault zone; 4 - degraded remains of the NIMPS; 5 - fluvial level at 650-600 m a.s.l.; 6 - fluvial level at $\sim 365 \mathrm{~m}$ a.s.l. ( + $262 \mathrm{~m}$ a.r.b.); T9 to T1 - terrace levels; al. - alluvial plain.

network to have incised and kept pace with uplift (e.g. Stokes and Mather, 2003). This would require that an exorheic system traversing Iberia to the Atlantic coast to have already been established as part of the earliest mid-Neogene drainage pattern. Clearly this was not the case, since distinct endorheic (Douro Cenozoic Basin) and exorheic (Mondego Cenozoic Basin) systems were functioning as separate drainage systems in (and before) the early Pliocene. Tectonic uplift occurred in the study area during the generation of the Mountains and Plateaus of Northern Portugal, from the middle Tortonian ( $\sim 9.6 \mathrm{Ma})$ to the mid-late Pliocene $(\sim 3.7 \mathrm{Ma})$. However, the sedimentary, geomorphological and tectonic evidence suggests most of the regional drainage was received at that time by the endorheic Douro Cenozoic Basin (e.g., Pais et al., 2012; Cunha, 2019). Thus the endorheic to exorheic drainage reorganization would seem to be more readily explained in terms of 'bottom-up' capture-related headward fluvial erosion of an Atlantic draining river or by 'top-down' basin-overspill mechanisms.

River capture studies routinely document changes in sediment facies, palaeoflow evidence, provenance and grain-size characteristics (e.g. Harvey and Wells, 1987). For example, a system that has captured

Table 2

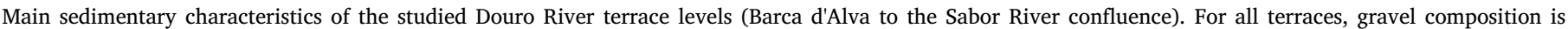
dominated by quartzite (milky quartz appearance), whereas sands are typically of arkosic composition.

\begin{tabular}{|c|c|c|c|}
\hline Geomorphic level & Elevation a.r.b (m) & $\begin{array}{l}\text { Maximal thickness } \\
(\mathrm{m})\end{array}$ & Sedimentary characteristics \\
\hline T3 terrace & +53 to +48 & ca. 12 & $\begin{array}{l}\text { Boulder gravel terrace, }>10 \mathrm{~m} \text {-thick at Barca d'Alva, clast-supported, with rare interbedded sand lenses } \\
\text { (Fig. 12). At Qta. do Vale Meão there are fluvial channel fills of brown-reddish boulder gravels, which include } \\
\text { lenses of coarse to medium sands and rare coarse silt levels. Boulders of quartzite up to } 55 \mathrm{~cm} \text { in diameter are } \\
\text { common. Contains archaeological remains of Acheulian industries. }\end{array}$ \\
\hline T2 terrace & +34 to +27 & ca. 18 & Clast-supported cobble gravels, with interbedded sand lenses. \\
\hline T1 terrace & +17 to +13 & 11 & $\begin{array}{l}\text { Comprises only compact fine to very fine sands and sandy silts of pale fawn colour. There is fossil root } \\
\text { bioturbation at the top of channel filling sequences ( } 1-2 \mathrm{~m} \text { thick) and small pedogenic carbonate concretions } \\
\text { within the topmost deposits. }\end{array}$ \\
\hline Alluvial plain & +10 & 10 & $\begin{array}{l}\text { Whitish fine friable sands (e.g. recent exposure made by channel down-cutting just downstream of the Pocinho } \\
\text { dam). }\end{array}$ \\
\hline Modern river bed & +0 & ca. 2 & Coarse sands to gravels, overlying the Variscan basement. \\
\hline
\end{tabular}


Table 3

Geographic coordinates, burial depth, water content and radionuclide activities used for dose rate calculation.

\begin{tabular}{|c|c|c|c|c|c|c|c|c|}
\hline NLL and field codes & $\begin{array}{l}\text { Geographic coordinates } \\
(\mathrm{M}, \mathrm{P})\end{array}$ & $\begin{array}{l}\text { Sample altitude } \\
\text { (m) }\end{array}$ & $\begin{array}{l}\text { Burial depth } \\
\text { (cm) }\end{array}$ & $\begin{array}{l}\text { Water content } \\
(\%)\end{array}$ & $\begin{array}{l}\mathrm{U}-238 \\
\left(\mathrm{~Bq} \mathrm{~kg}{ }^{-1}\right)\end{array}$ & $\mathrm{Ra}-226\left(\mathrm{~Bq} \mathrm{~kg}{ }^{-1}\right)$ & $\begin{array}{l}\text { Th-232 } \\
\left(\mathrm{Bq} \mathrm{kg}^{-1}\right)\end{array}$ & $\mathrm{K}-40\left(\mathrm{~Bq} \mathrm{~kg}^{-1}\right)$ \\
\hline 102211 T1VM-1 & $\mathrm{N} 41^{\circ} 10^{\prime} 0.65^{\prime \prime} \mathrm{W} 7^{\circ} 6^{\prime} 53.46^{\prime \prime}$ & $119.5(+13.5)$ & 655 & $15(3 ; 30)$ & $57 \pm 8$ & $47.7 \pm 0.8$ & $59.3 \pm 0.9$ & $644 \pm 13$ \\
\hline 102212 T1VM-6 & $\mathrm{N} 41^{\circ} 10^{\prime} 0.65^{\prime \prime} \mathrm{W} 7^{\circ} 6^{\prime} 53.46^{\prime \prime}$ & $123(+17)$ & 285 & $15(4 ; 24)$ & $41 \pm 6$ & $41.1 \pm 0.6$ & $47.8 \pm 0.7$ & $567 \pm 11$ \\
\hline 102213 BALVA-2 & N41 $01^{\prime} 53^{\prime \prime}$ W006 $55^{\prime} 50^{\prime \prime}$ & $158(+45 \mathrm{~m})$ & 300 & $7(1 ; 11)$ & $18 \pm 6$ & $17.1 \pm 0.5$ & $19.7 \pm 0.5$ & $826 \pm 16$ \\
\hline 102214 BALVA-1 & $\begin{array}{l}\mathrm{N} 41^{\circ} 01^{\prime} 24.09^{\prime \prime} \\
\mathrm{W} 6^{\circ} 56^{\prime} 9.87^{\prime \prime}\end{array}$ & $178(+65 \mathrm{~m})$ & 40 & $10(5 ; 20)$ & $43 \pm 6$ & $49.3 \pm 0.7$ & $66.4 \pm 0.8$ & $645 \pm 12$ \\
\hline 102215 POCINHO-2 & $\mathrm{N} 41^{\circ} 8^{\prime} 12.41^{\prime \prime} \mathrm{W} 7^{\circ} 7^{\prime} 13.12^{\prime \prime}$ & $151(+45)$ & 800 & $12(8 ; 22)$ & $29 \pm 7$ & $15.5 \pm 0.5$ & $25.3 \pm 0.6$ & $1040 \pm 20$ \\
\hline 102216 POCINHO-1 & $\mathrm{N} 41^{\circ} 8^{\prime} 11.47^{\prime \prime} \mathrm{W} 7^{\circ} 7^{\prime} 13.01^{\prime \prime}$ & $153(+47)$ & 600 & $8(2 ; 14)$ & $15 \pm 5$ & $13.8 \pm 0.4$ & $24.3 \pm 0.5$ & $755 \pm 14$ \\
\hline 102217 RBARCA-1 & $\mathrm{N} 41^{\circ} 10^{\prime} 19^{\prime \prime}$ W007 $6^{\prime} 32^{\prime \prime}$ & $131(+25)$ & 80 & $14(13 ; 26)$ & $38 \pm 8$ & $36.1 \pm 0.7$ & $55.3 \pm 0.9$ & $548 \pm 12$ \\
\hline 102218 CVEIGA-1 & N41 $07^{\prime} 59^{\prime \prime}$ W007 $7^{\prime} 51^{\prime \prime}$ & $124(+18)$ & 210 & $10(6 ; 23)$ & $31 \pm 7$ & $39.3 \pm 0.7$ & $50.1 \pm 0.8$ & $562 \pm 12$ \\
\hline 102219 T1VM-7 & $\mathrm{N} 41^{\circ} 10^{\prime} 0.65^{\prime \prime} 7^{\circ} 6^{\prime} 53.46^{\prime \prime}$ & $125(+19)$ & 90 & $17(9 ; 27)$ & $52 \pm 8$ & $51.2 \pm 0.8$ & $54.0 \pm 0.9$ & $592 \pm 13$ \\
\hline 102220 CVEIGA-4 & $\mathrm{N} 41^{\circ} 8^{\prime} 1.40^{\prime \prime} \mathrm{W} 7^{\circ} 7^{\prime} 49.80^{\prime \prime}$ & $123(+17)$ & 200 & $8(1 ; 16)$ & $15 \pm 6$ & $22.5 \pm 0.5$ & $25.8 \pm 0.6$ & $756 \pm 14$ \\
\hline 102221 POCINHO-0 & N41 $07^{\circ} 59^{\prime \prime}$ W007 $7^{\prime} 51^{\prime \prime}$ & $106(+0)$ & 10 & $18(17 ; 21)$ & $145 \pm 7$ & $138.1 \pm 1.3$ & $67.6 \pm 0.8$ & $1273 \pm 21$ \\
\hline 112233 BALVA-3 & $\mathrm{N} 41^{\circ} 01^{\prime} 34^{\prime \prime} \mathrm{W} 006^{\circ} 56^{\prime} 31^{\prime \prime}$ & $160.5(+47.5)$ & 1100 & $6(10 ; 13)$ & $40 \pm 5$ & $24.2 \pm 0.5$ & $39.9 \pm 0.7$ & $372 \pm 9$ \\
\hline 112234 ALMENDRA-1 & $\mathrm{N} 41^{\circ} 02^{\prime} 08^{\prime \prime} \mathrm{W} 007^{\circ} 0^{\prime} 10^{\prime \prime}$ & $113(+0)$ & 5 & $25(25 ; 25)$ & $17 \pm 5$ & $24.8 \pm 0.4$ & $35.3 \pm 0.6$ & $639 \pm 11$ \\
\hline
\end{tabular}

other drainage would show evidence of an enlarged catchment area, such as elevated sediment/water discharges being delivered downstream as the captured headwaters undergo upstream propagation of a fluvial incision wave as an adjustment to connection with a new and lower base level. The new larger system could also have lower downstream gradient, this being proportional to catchment size. The elevated sediment/water fluxes result in marked increases in grain size and changes to fluvial sedimentation styles (e.g. fluvial pattern change: meandering to braided). The addition of new areas to the catchment might also result in different rocks becoming available to headwaters and thus being recorded in downstream fluvial sediment deposited post-capture. In the Lower Douro, the early drainage is recorded as basin sedimentary infill adjacent to the coast (the Mondego Cenozoic Basin). Sedimentary and palaeogeographic reconstructions (Cunha, 2019) reveal a fine-grained sandy braided drainage system connected to the Atlantic with sediment provenanced from localized coastal relief. This older drainage system thus lacks sedimentary evidence for capture.

The younger drainage system of the Lower Douro is recorded within inset sequences of river terraces. These terraces appear to have a temporal and spatial relationship to similar sequences upstream within the DCB. Sediment in these terraces sequences can be shown to have been transported downstream from the DCB into the Lower Douro towards the Atlantic coast (Silva et al., 2017). The terraces have similarities in sedimentary style and clast provenance that lack any unequivocal signature of capture (e.g., Harvey and Wells, 1987; Harvey et al., 1995). The continuity of terraces throughout the Douro catchment and the evidence for palaeoflow towards the Atlantic suggests that the drainage reorganization pre-dated terrace formation and correlate to the initiation of drainage to the coastal basin. Neither of these Lower Douro systems provides compelling evidence for capture-related drainage reorganization. If capture occurred, evidence for it is missing from the Lower Douro region, perhaps due to headward erosion by migrating knickpoints (e.g. Struth et al., 2019). If a capture-related wave of incision had propagated upstream along the WMDCB, its progress would have been limited by the resistant granite (e.g. Struth et al., 2019). However, the shape of the modern Douro long profile (Fig. 1) lacks any clear capture signature, instead having a morphology that,reflects a combination of rock strength and adjustment after the exorheic drainage re-organisation occurred.

Overspill requires water to cross a catchment divide and is a widely cited explanation for drainage reorganization from many studies from tectonically elevated regions, with either mountainous relief and/or high-elevation plateaus (e.g. Grand Canyon: Douglass et al., 2009; Tibetan Plateau: Craddock et al., 2010). The process typically involves the growth of a lake, with an increase in water level which ultimately reaches the level of the catchment divide, over which the rising water spills. Classic examples of overspill come from the internally drained
Great Basin region of the SW USA, where lake-level changes linked to Pleistocene glacial/pluvial periods can be tracked by the positions of shoreline sequences (Tchakerian and Lancaster, 2002), with relationships to eroded canyons (gorges) and fluvial terraces downstream of overspill sites (e.g. Menges, 2008). In the present study, the DCB has a lacustrine configuration, but this evidence is derived from the sedimentary basin infill alone; geomorphological lake-shoreline terraces are absent. The CDB lake may have extended downstream through the WMDCB and into the study area (uppermost reach of the Lower Douro). However, evidence is restricted to fragmentary remnants of high-level ( $\sim 665-365 \mathrm{~m}$ a.s.1.) surfaces of wide landscape extent (Figs. 4 and 5) but lacking sediments. The $650-600 \mathrm{~m}$ a.s.l. surface ends along the margins of the Montemuro-Marão upland in the Mesão Frio area (Fig. 4), with no downstream continuation, suggesting that this location was the limit of potential lacustrine extent, with the position of the drainage divide lithologically controlled by resistant granite and quartzite basement lithologies (Figs. 1, 2 and 4). Upstream of Mesão Frio, as far as Barca d'Alva, the dominance of weak metamorphic lithologies would have helped any overflow from a lake/ponded system to incise the erosional surface. Regional westward tectonic tilting (Section 5.1) may have helped promote ponding in this area. Furthermore, the warm and humid climate of the middle Pliocene would have promoted expansion and water-level rise in lake-systems, but improved age control is needed to establish this relationship with greater security. The inset $\sim 575-365 \mathrm{~m}$ a.s.l. surface extends downstream beyond the Montemuro-Marão upland into the Lower Douro (Fig. 4). Its genetic origin is unclear but its inset nature and continuation downstream, where it is cut into granite bedrock (Figs. 1, 2 and 4), suggests that a fluvial origin is more likely. When the high-level surfaces are considered together, it seems likely that drainage reorganization occurred with the formation of the $650-600 \mathrm{~m}$ level; the formation of the 575-365 m level can be related to clear exorheic drainage. Collectively, evidence from the surface geomorphology, rock strength, tectonic and climatic relationships of these surfaces appear to integrate well and provide marginally more compelling evidence for overspill than for capture as the mechanism for drainage reorganization.

\subsection{Endorheic to exorheic drainage transition in the Douro}

Integration of the previously discussed controls and mechanisms for drainage evolution has allowed a conceptual model for the endorheic to exorheic transition of the Douro to be established. We consider this transition to have occurred in four stages:

Stage 1: The initial stage involved the development of the endorheic DCB. The DCB was formed and filled as an intermontane foreland basin. Along its western margin, it tapered into a high-elevation plateau formed from regionally eroded igneous and metamorphic basement, 


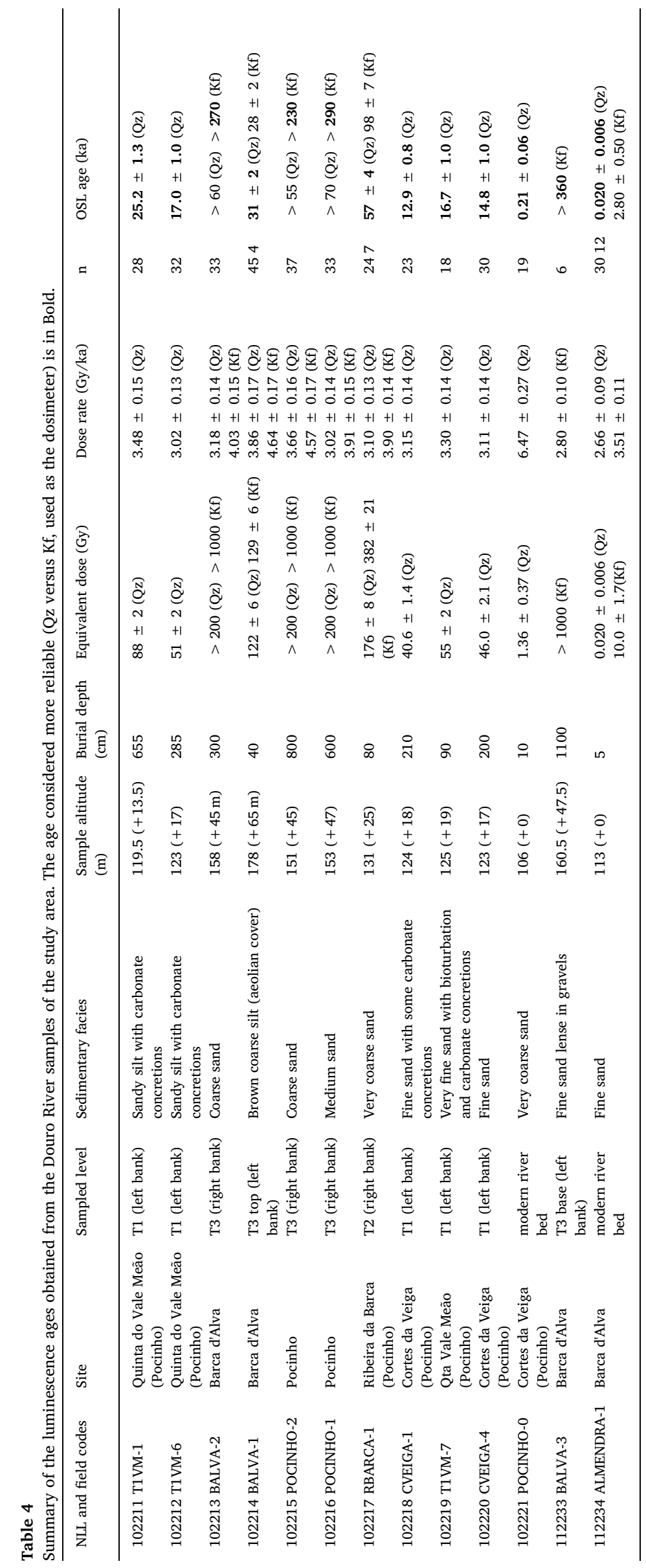




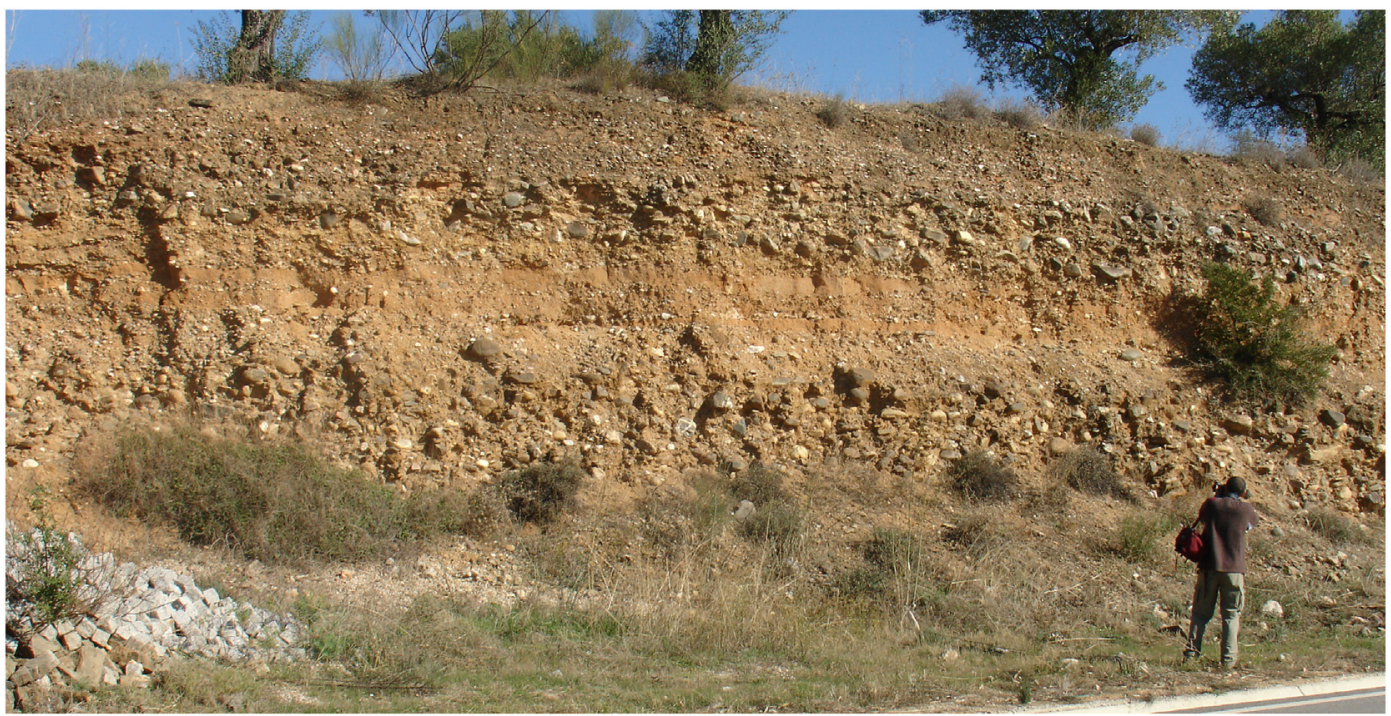

Fig. 12. Photo illustrating the $\mathrm{T} 3$ terrace deposits at Barca d'Alva, Douro right bank. The large lense of medium sand located in the middle part of the exposure was sampled for OSL dating (sample 102213; BALVA-2; $158 \mathrm{~m}$ a.s.l., $+45 \mathrm{~m}$ a.r.b.).

shaped between the early Cretaceous and the late Cenozoic. The MPNP and NIMPS mark the western extent of the endorheic DCB. Evidence for a contemporaneous Atlantic drainage system is lacking.

Stage 2: This marks the onset of drainage reorganization. Westward tectonic tilting of the DCB and elevated Pliocene hydrological conditions resulted in ponding and the development of an extended lake system, resulting in a high-level fluvial surface at 600-650 $\mathrm{m}$ a.s.1. This surface, although now fragmentary, seems to have had a widespread spatial extent within the tectonic depressions along the westernmost margin of the endorheic system (i.e. between Mesão Frio and Barca d'Alva in the uppermost reach of the Lower Douro). The endorheic system was confined by a drainage divide in resistant geology at Mesão Frio. The overspilling of this divide as a result of elevated water levels initiated erosion and breaching of this barrier, marking the onset of exorheic drainage (Fig. 14).
Stage 3: Headward erosion, initiated by the overspill and subsequently progressing upstream into the depression and further into the WMDCB was moderated by the variable resistance to erosion of the metamorphic and granite basement (Fig. 15). The 575-365 ma.s.l. surface within the uppermost Lower Douro depression marks the establishment of exorheic drainage, but a full connection with the Mondego Cenozoic Basin was probably yet to be established. Age modelling using the incision rates of dated river terrace deposits (Stage 4) suggests that the 575-365 ma.s.l. surface was developed during the early Pleistocene $(\sim 1.8 \mathrm{Ma})$. This implies that drainage reorganization occurred during the Pliocene.

Stage 4: This final stage of drainage evolution was marked by enhanced vertical downcutting, during which river terrace staircases developed, both within the study area (Figs. 6, 9, 10, 11) and upstream in the DCB (Silva et al., 2017). This stage, with rapid incision, represents

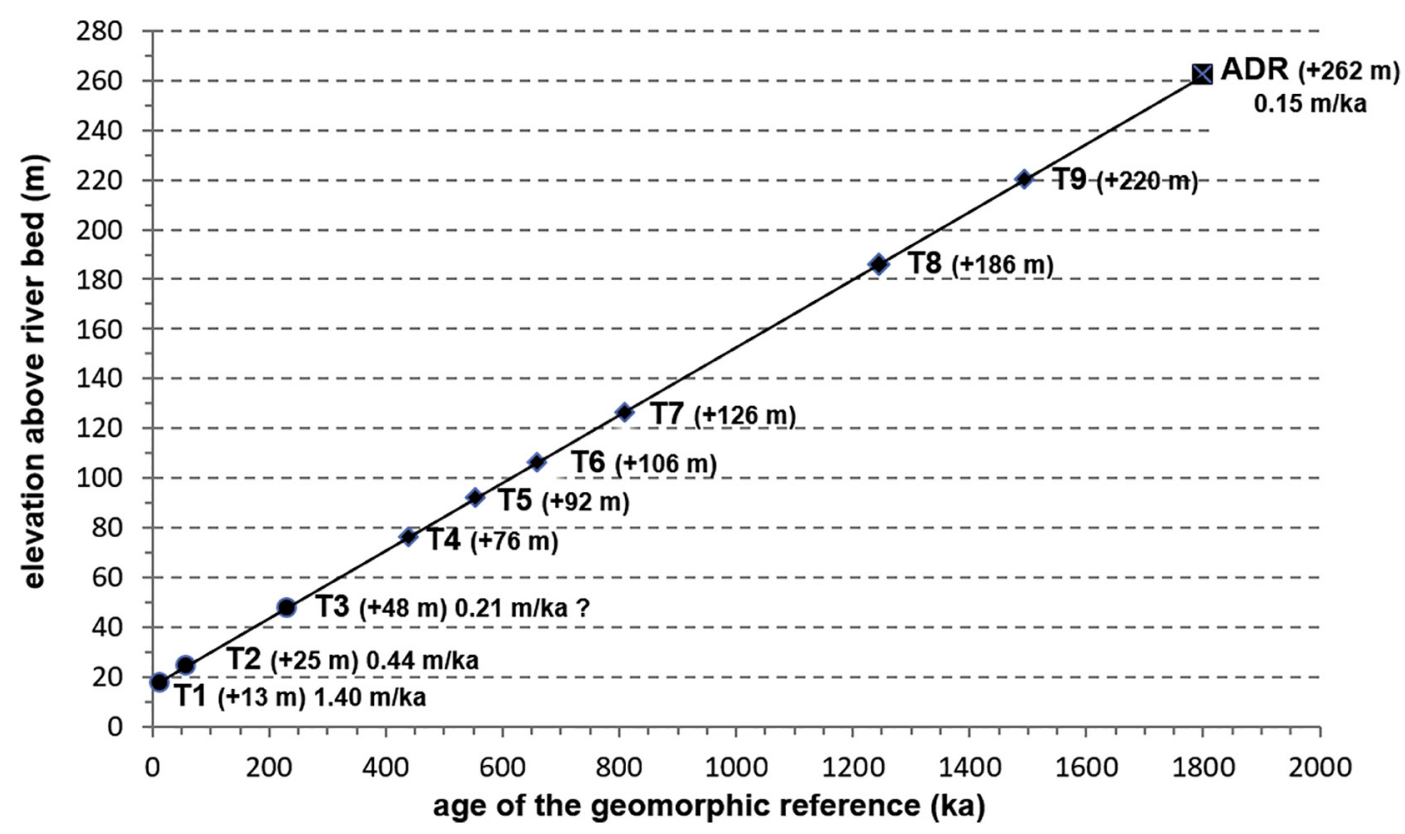

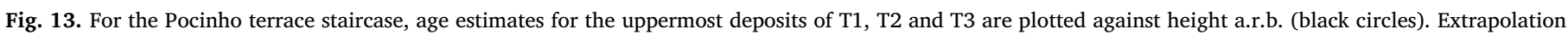

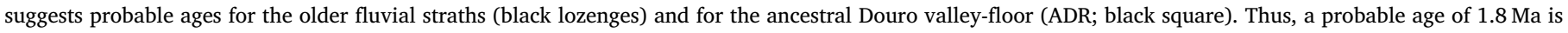
likely for the onset of enhanced fluvial incision. 


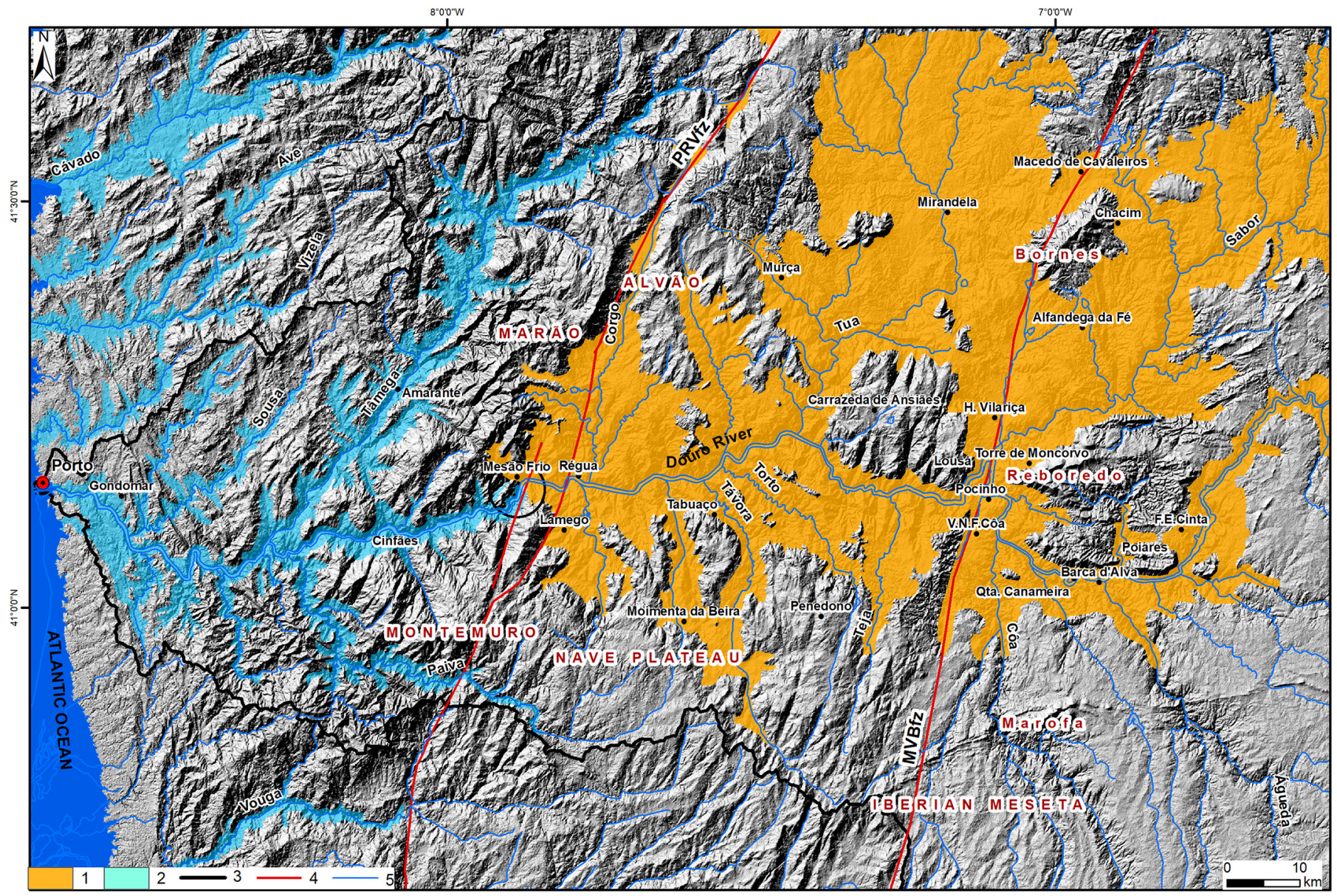

Fig. 14. Palaeogeographic reconstruction of overspill from the Douro Cenozoic Basin, at $\sim 3.7 \mathrm{Ma}$, through the former Montemuro-Marão drainage divide. The interpreted westward overflow generated the widespread $\sim 650-600 \mathrm{~m}$ a.s.l. fluvial level (ochre colour) represented in the study area (Freixo de Espada à Cinta Régua). Basin overspill, at a location just downstream of Régua (Mesão Frio), established a definitive conection with Atlantic drainage. 1 - 650-600 m a.s.l. fluvial level; 2 - Atlantic river valleys; 3 - drainage divide; 4 - main faults; 5 - main present-day rivers; black circle - Mesão Frio outlet, formed by overspill.

full connection with the upstream DCB, with an acceleration of headwards erosion into the weak sedimentary basin infill. The granite basement of the WMDCB limited the incision and is manifested as a significant knick-zone with deeply incised canyon/gorge systems (e.g. Arribas do Douro).

\section{Conclusions}

In the sector of the Lower Douro located immediately downstream of the large Arribas do Douro knick-zone, several geomorphic elements can be recognized: (i) a planation surface (NIMPS and MPNP), with a regional gradient towards the Douro Cenozoic Basin, but displaced by late Cenozoic tectonic modification; (ii) a widespread Douro level at $\sim 650-600 \mathrm{~m}$ a.s.l., corresponding to the initiation of regional drainage reversal along a ESE-WNW depression, probably established at $\sim 3.7 \mathrm{Ma}$; (iii) a Douro level at 575-365 ma.s.l., interpreted as representing the valley of the ancestral Douro (progressive drainage evolution); (iv) the narrow and entrenched lower part of the Douro valley, incised bellow the paleo-valley floor of the ancestral Douro (accelerated drainage evolution). The entrenched part of the valley records the subsequent enhanced fluvial incision by the Atlantic drainage and locally displays a maximum of nine straths, the three lower ones with sedimentary deposits.

The transition from the former internal drainage of the Douro Cenozoic Basin (endorheic stage) to Atlantic Douro drainage (exorheic stage) is best explained by a combination of two drivers: (i) increasing intraplate compression, that progressivelly tilted the Douro Cenozoic
Basin towards the west, and (ii) a major climate change by $\sim 3.7 \mathrm{Ma}$ (transition to a wetter climate stage), from the generally dry and hot climate during the Miocene and Zanclean to the humid and hot climate of the late Zanclean to Piacenzian.

The latest stage (last $\sim 2 \mathrm{Ma}$ ), marked by enhanced fluvial incision, is related to continuous regional low crustal uplift, cooler climatic minima and associated lowering of sea level. The progressive extension of the Atlantic coastal drainage system into the Douro Cenozoic Basin drove a progressive increase in discharge, and thus incision, in the Lower Douro, explaining the progressive entrenchment of the valley. Bedrock (strath) terraces can be correlated along the longitudinal profile of the Lower Douro over considerable distances, pointing to amost synchronous development rather than the result of a unique wave of incision transmitting upstream during the Pleistocene.

\section{Funding}

This research was supported by the Fundação para a Ciência e a Tecnologia, through project PTDC/CTE-GIN/66283/2006 (Paleoseismological study of active faults in mainland Portugal), and partially co-funded by the European Union through the European Regional Development Fund, based on COMPETE 2020 (Programa Operacional da Competitividade e Internacionalização), through projects UID/MAR/04292/2019 - MARE (PPC), UID/GEO/04683/2019 ICT (AAM and DP), UID/GEO/04084/2019 (AG), UID/GEO/50019/ 2019 - IDL (JC) and UID/Multi/00611/2019 (FCL). 


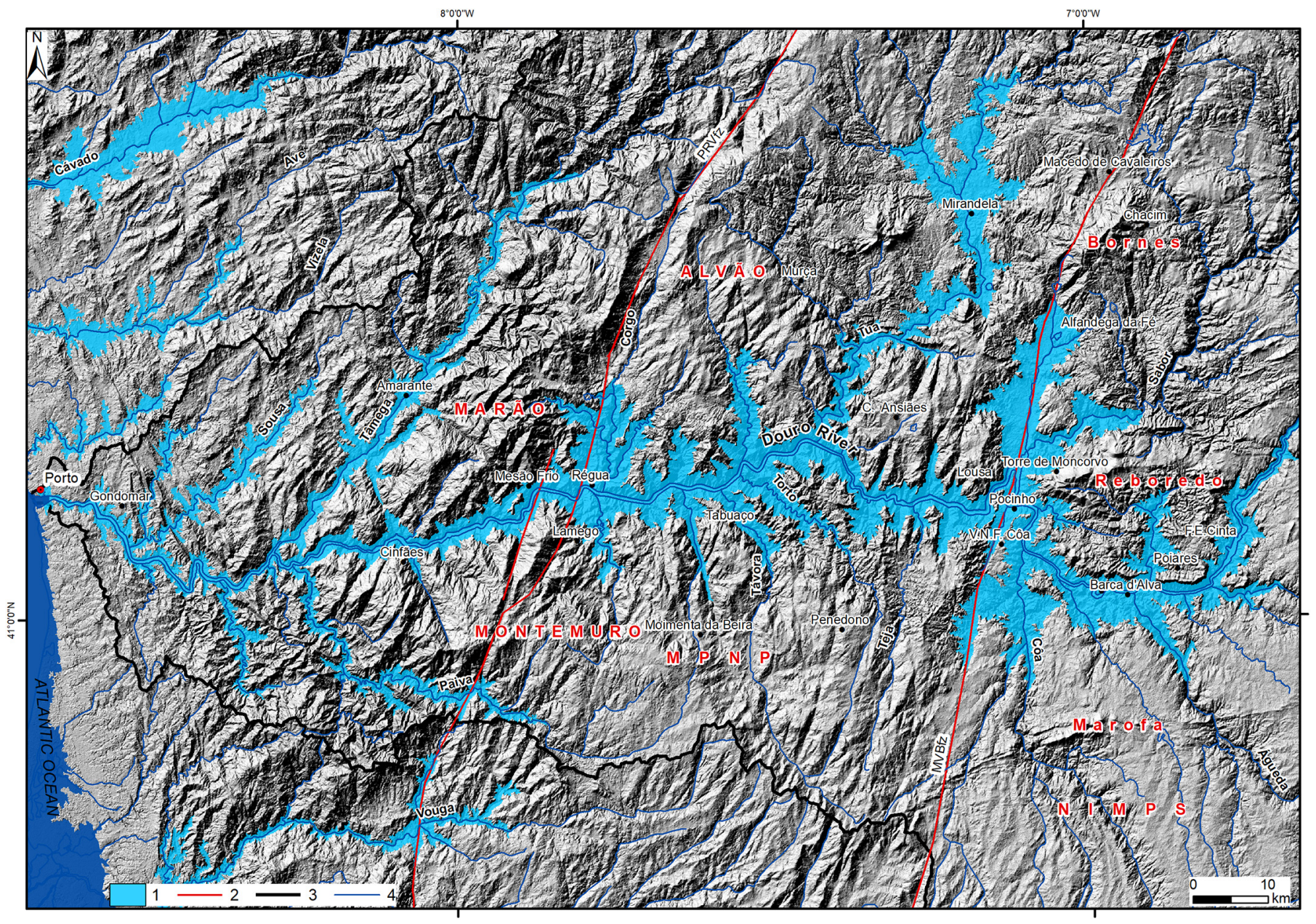

Fig. 15. Palaeogeographic reconstruction of the ancestral Douro River and its main tributaries, at $\sim 3.6-2 \mathrm{Ma}$ (just before the rapid fluvial incision began - Stage 4 ). 1 - 575-365 m a.s.l. fluvial level; 2 - main faults; 3 - drainage divide; 4 - main present-day rivers.

\section{Declaration of Competing Interests}

The authors declare no conflict of interest. The funders had no role in the design of the study; in the collection, analyses, or interpretation of data; in the writing of the manuscript, or in the decision to publish the results.

\section{Acknowledgments}

Prof. Suzanne Daveau is thanked for comments and suggestions of improvements to the manuscript. The authors also thank the relevant contributions made by Prof. David Bridgland, as Managing Guest Editor, and by the reviewers. This work is dedicated to Prof. António Brum Ferreira, who has recently passed away, in acknowledgment to his significant research contribution to the Geomorphology of northern Portugal.

\section{Appendix A. Supplementary data}

Supplementary data to this article can be found online at https:// doi.org/10.1016/j.gloplacha.2019.102985.

\section{References}

\footnotetext{
Alonso-Gavilán, G., Armenteros, I., Carballeira, J., Corrochano, A., Huerta, P., Rodríguez, J.M., 2004. Cuenca del duero. In: Vera, J.A.E. (Ed.), Geología de España. Sociedad Geológica de España-IGME, Madrid, pp. 550-556.
}

Alonso-Zarza, A.M., Armenteros, I., Braga, J.C., Munoz, A., Pujalte, V., Ramos, E.,
Aguirre, J., Alonso Gavilan, G., Arenas, C., Baceta, J.I., Carballeira, J., Calvo, J.P. Corrochano, A., Fornos, J.J., Gonzalez, A., Luzon, A., Martin, J.M., Pardo, G., Payros, A., Perez, A., Pomar, L., Rodriguez, J.M., Villena, J., 2002. Tertiary. In: Gibbons, W., Moreno, T. (Eds.), The Geology of Spain. Geological Society, Bath, pp. 293-334. https://www.geolsoc.org.uk/GOSPP.

Antón, L., Rodés, A., de Vicente, G., Pallàs, R., Garcia-Castellanos, D., Stuart, F.M., Braucher, R., Bourlès, D., 2012. Quantification of fluvial incision in the Duero Basin (NW Iberia) from longitudinal profile analysis and terrestrial cosmogenic nuclide concentrations. Geomorphology 165, 50-61. https://doi.org/10.1016/j.geomorph. 2011.12.036.

Antón, L., de Vicente, G., Muñoz-Martín, A., Stokes, M., 2014. Using river long profiles and geomorphic indices to evaluate the geomorphological signature of continental scale drainage capture, duero basin (NW Iberia). Geomorphology 206, 250-261. https://doi.org/10.1016/j.geomorph.2013.09.028.

Antón, L., Mather, A.E., Stokes, M., Munoz-Martin, A., de Vicente, G., 2015. Exceptional river gorge formation from unexceptional floods. Nat. Commun. 6, 7963. https://doi. org/10.1038/ncomms8963.

Antón, L., Muñoz-Martín, A., de Vicente, G., 2018. Quantifying the erosional impact of a continental-scale drainage capture in the Duero Basin, northwest Iberia. Quaternary Research 91 (2), 457-471. https://doi.org/10.1017/qua.2018.38.

Araújo, M.A., Gomes, A., Chaminé, H.I., Fonseca, P.E., Gama Pereira, L.C., Pinto de Jesus, A., 2003. Geomorfologia e geologia regional do sector de Porto-Espinho (W de Portugal): implicacoes morfoestruturais na cobertura sedimentar cenozoica. Cadernos do Laboratorio Xeoloxico de Laxe 28, 79-105.

Barrón, E., Rivas-Carballo, R., Postigo-Mijarra, J.M., Alcalde-Olivares, C., Vieira, M., Castro, L., Valle-Hernández, M., 2010. The Cenozoic vegetation of the Iberian Peninsula: a synthesis. Rev. Palaeobot. Palynol. 162, 382-402. https://doi.org/10 1016/j.revpalbo.2009.11.007.

Boulton, S.J., Stokes, M., 2018. Which DEM is best for analyzing fluvial landscape development in mountainous terrains? Geomorphology 310, 168-187. https://doi.org/ 10.1016/j.geomorph.2018.03.002.

Bridgland, R., 2000. River terrace systems in north-West Europe: an archive of environmental change, uplift and early human occupation. Quat. Sci. Rev. 19, 1293-1303.

Bridgland, D.R., Westaway, R., 2012. The use of fluvial archives in reconstructing landscape evolution: the value of sedimentary and morphostratigraphical evidence. Neth. J. Geosci. 91, 5-24. 
Bridgland, D., Westaway, R., 2014. Quaternary fluvial archives and landscape evolution: a global synthesis. Proc. Geol. Assoc. 125, 600-629.

Cabral, J., 1989. An example of intraplate neotectonic activity, Vilariça basin, Northeast Portugal. Tectonics 8, 285-303. https://doi.org/10.1029/TC008i002p00285.

Cabral, J., 1995. Neotectónica em portugal continental. Mem. Inst. Geol. e Min 31, 265 Lisboa.

Cabral, J., 2012. Neotectonics of mainland Portugal: state of the art and future perspectives. J. Iber. Geol. 38 (1), 71-84.

Cabral, J., Perea, H., Figueiredo, P.M., Besana-Ostman, G., Brum da Silveira, A., Cunha, P.P., Gomes, A., Lopes, F.C., Pereira, D., Rockwell, T., 2010. Preliminary results of a paleoseismological study of the Vilariça fault (NE Portugal). In: Insua, J.M., Martín González, F. (Eds.), Contribución de la Geología al Análisis de la Peligrosidad Sísmica, Livro de Resumos da $1^{\mathrm{a}}$ Reunião Ibérica sobre Falhas Activas e Paleossismologia, Sigüenza. Espanha, Guadalajara, pp. 41-44.

Cachão, M.A., 1990. Posicionamento biostratigráfico da jazida pliocénica de Carnide. Gaia 2, 11-16.

Costa, J.C., Teixeira, C., 1957. Carta Geológica de Portugal na escala de 1/50 000. In: Notícia explicativa da Folha 9-C (Porto). Portugal, Lisboa, Serv. Geol, pp. 38.

Craddock, W.H., Kirby, E., Harkins, N.W., Zhang, H., Shi, X., Liu, J., 2010. Rapid flu-vial incision along the Yellow River during headward basin integration. Nat. Geosci. 3 (3), 209-213.

Cunha, P.P., 1992a. Estratigrafia e sedimentologia dos depósitos do Cretácico Superior e terciário de portugal central. In: A Leste De Coimbra/Stratigraphy And Sedimentology Of The Upper Cretaceous And Tertiary In Central Portugal, East Of Coimbra. University of Coimbra, pp. 262. Ph.D. Thesis. https://estudogeral.sib.uc. pt/handle/10316/2015.

Cunha, P.P., 1992b. Establishment of unconformity-bounded sequences in the cenozoic record of the western iberian margin and synthesis of the tectonic and sedimentary evolution in central Portugal during neogene. In: First Congress R.C.A.N.S. - "Atlantic General Events During Neogene" Abstracts Book, pp. 33-35 Lisboa.

Cunha, P.P., 2000. Paleoalterações e cimentações nos depósitos continentais terciários de Portugal central: importância na interpretação de processos antigos. Ciên. Da Terra 14, 145-154.

Cunha, P.P., 2019. Cenozoic Basins of Western Iberia: Mondego, Lower Tejo and Alvalade basins. In: Quesada, C., Oliveira, J.T. (Eds.), The Geology of Iberia: A Geodynamic Approach. Regional Geology Reviews. Cenozoic Basins Vol. 4. Springer International Publishing, pp. 105-130. https://doi.org/10.1007/978-3-030-11190-8_4. Chapter 4, Book ID: 473223_1_En, Book ISBN: 978-3-030-11189-2.

Cunha, P.P., Pereira, D.I., 2000. Evolução cenozóica da área de Longroiva-Vilariça (NE Portugal). Ciên. da Terra 14, 89-198. https://run.unl.pt/handle/10362/4689.

Cunha, P.P., Barbosa, B.P., Pena dos Reis, R., 1993. Synthesis of the Piacenzian onshore record between the Aveiro and Setúbal parallels (Western Portuguese margin). Ciên. da Terra 12, 35-43. https://run.unl.pt/bitstream/10362/3296/1/CT_12_03.pdf.

Cunha, P.P., Pimentel, N., Pereira, D.I., 2000. A assinatura tectono-sedimentar do auge da compressão bética em Portugal: a descontinuidade sedimentar Valesiano terminalTuroliano. Ciên. da Terra 14, 61-72 (cienciasdaterra.novaidfct.pt/index.php/ct-esj/ article/view/180/183).

Cunha, P.P., Almeida, N.A.C., Aubry, T., Martins, A.A., Murray, A.S., Buylaert, J.-P., Sohbati, R., Raposo, L., Rocha, L., 2012. Records of human occupation from Pleistocene river terrace and aeolian sediments in the arneiro depression (Lower Tejo River, central eastern Portugal). Geomorphology 165-166, 78-90. https://doi.org/ 10.1016/j.geomorph.2012.02.017.

Cunha, P.P., Martins, A.A., Gouveia, M.P., 2016. The terrace staircases of the Lower Tagus River (Ródão to Chamusca) - characterization and interpretation of the sedimentary, tectonic, climatic and Palaeolithic data. Estud. do Quater. 14, 1-24. Doi:10.30893/eq. v0i14.116.

Cunha, P.P., Martins, A., Buylaert, J.-P., Murray, A.S., Raposo, L., Mozzi, P., Stokes, M., 2017. New data on the chronology of the vale do Forno sedimentary sequence (Lower Tejo River terrace staircase) and its relevance as a fluvial archive of the Middle Pleistocene in western Iberia. Quat. Sci. Rev. 166, 204-226. https://doi.org/10. 1016/j.quascirev.2016.11.001.

Cunha, P.P., de Vicente, G., Martín-González, F., 2019. Cenozoic sedimentation Along the piedmonts of thrust related basement ranges and Strike-slip deformation belts of the Iberian Variscan Massif. In: Quesada, C., Oliveira, J.T. (Eds.), The Geology of Iberia: a Geodynamic Approach. Regional Geology Review Series 4 Springer Nature Switzerland AG. https://doi.org/10.1007/978-3-030-11190-8_5. Chapter 5, Book ID: 473223_1_En Book ISBN: 978-3-030-11189-2.

Dantin, J., 1912. Resumen fisiográfico de la Península Ibérica. Trab. Museo Nac. Cien. Nat S. Geol. 9, 275 (Madrid).

de Vicente, G., Vegas, R., Cabral, J., Van Wees, J.D., Olaiz, A., 2008. Corredores de desgarre cenozoicos en la Península Ibérica (Cenozoic strike-slip corridors of the Iberian Península). Geo-Temas 10, 333-336.

de Vicente, G., Cloetingh, S., Van Wees, J.D., Cunha, P.P., 2011. Tectonic classification of Cenozoic Iberian foreland basins. Tectonophysics 502, 38-61. https://doi.org/10. 1016/j.tecto.2011.02.007.

de Vicente, G., Cunha, P.P., Muñoz-Martín, A., Cloetingh, S.A.P.L., Olaiz, A., Vegas, R. 2018. The Spanish-Portuguese Central System: an example of intense intraplate deformation and strain partitioning. Tectonics 37, 4444-4469. https://doi.org/10. 1029/2018TC005204.

Douglass, J., Meek, N., Dorn, R.I., Schmeeckle, M.W., 2009. A criteria-based methodology for determining the mechanism of transverse drainage development, with application to the southwestern United States. GSA Bull. 121, 586-598. https://doi.org/10.1130/ B26131.1.

Feio, M., 1951. A depressão de Régua-Verín. Comun.dos Serv. Geológicos de Port. Lisboa 32 (1), 181-222.

Feio, M., Daveau, S., 2004. O Relevo de Portugal. Grandes Unidades Regionais,
Associação Portuguesa de Geomorfólogos, II, Coimbra (organiz).

Ferreira, A.B., 1971. O Rebordo Ocidental Da Meseta E A Depressão Da Longroiva. vol. 6. Finisterra, pp. 196-217. https://doi.org/10.18055/Finis2422.

Ferreira, A.B., 1978. Planaltos e montanhas do Norte da Beira. Estudo de geomorfologia. Mem. do Centro de Estud. Geogr. 4, 375 Lisboa.

Ferreira, A.B., 1980. Surfaces d'aplanissement et tectonique récente dans le Nord de la Beira (Portugal). In: Revue de Géologie dynamic et de Géographie physique. 22. pp. 51-62 Paris.

Ferreira, A.B., 1986. A Depressão de Chaves-Verín. Novas achegas para o seu conhecimento geomorfológico. Estudos em Homenagem a Mariano Feio, Lisboa, pp. 199-222.

Ferreira, A.B., 1991. Neotectonics in Northern Portugal: a geomorphological approach. Z. fur. Géom. 82, 73-85.

Ficher, T., 1894. Versuch einer wissenchaflinchen orographie der Iberischen Halbinsen. Pet. Mitt. 249-256 (Gotha).

Galve, J.P., Pérez-Peña, J.V., Azañón, J.M., Pereira, D.M.I., Cunha, P.P., Pereira, P., Ortuño, M., Viaplana-Muzas, M., Gracia Prieto, F.J., Remondo, J., Jabaloy, A., Bardají, T., Silva, P.G., Lario, J., Zazo, C., Goy, J.L., Dabrio, C.J., Cabero, A., 2019. Chapter 5 - Active landscapes of Iberia, pp. 77-124. In: Quesada, C., Oliveira, J.T. (Eds.), The Geology of Iberia: a Geodynamic Approach. Regional Geology Reviews 5. Springer Nature Switzerland AG, pp. 126. Active Processes: Seismicity, Active Faulting and Relief. eBook ISBN 978-3-030-10931-8. https://doi.org/10.1007/9783-030-10931-8 5 .

Garcia-Castellanos, D., Verges, J., Gaspar-Escribano, J., Cloetingh, S., 2003. Interplay between the tectonics, climate, and fluvial transport during the Cenozoic evolution of the Ebro Basin (NE Iberia). J. Geophys. Res. 108 (B7).

Gutierrez Elorza, M., Garcia Ruiz, J.M., Goy, J.L., Gracia Prieto, F.J., Gutierrez Santolalla, F., Marti, C., Martin Serrano, A., Pérez-González, A., Zazo, C., Aguirre, E., 2002. Quaternary. In: Gibbons, W., Moreno, T. (Eds.), The Geology of Spain. Geological Society, Bath, pp. 335-366.

Gutierrez-Elorza, M., Pérez-González, A., 1993. Geomorphology in Spain. In: Walker, H.J., Grabau, W.E. (Eds.), The Evolution of Geomorphology; A Nation-By Nation Summary of Development. John Wiley and Sons, Chichester, pp. 397-405.

Harvey, A.M., Wells, S., 1987. Response of quaternary fluvial systems to differential epeirogenic uplift: Aguas and Feos river systems, Southeast Spain. Geology 15, 689-693.

Harvey, A.M., Miller, S.Y., Wells, S.G., 1995. Quaternary soil and river terrace sequences in the Aguas/Feos river systems: Sorbas basin, Southeast Spain. In: Lewin, J., Macklin, M.G., Woodward, J.C. (Eds.), Mediterranean Quaternary River Environments. Balkema: Rotterdam, The Netherlands, pp. 263-281.

Heidarzadeh, G., Ballato, P., Hassanzadeh, J., Ghassemi, M.R., Strecker, M.R., 2017. Lake overspill and onset of fluvial incision in the Iranian Plateau: insights from the Mianeh Basin. Earth Planet. Sci. Lett. 469, 135-147. https://doi.org/10.1016/j.epsl.2017.04. 019.

Hernandez-Pacheco, E., 1911. Elementos geográfico-geológicos da Península Ibérica. Assoc. Esp. Prog. Ciências 5, 225-231.

House, P.K., Pearthree, P.A., Perkins, M.E., 2008. Stratigraphic evidence for the role of lake spillover in the inception of the lower Colorado River in southern Nevada and western Arizona. In: Reheis, M.C., Hershler, R., Miller, D.M. (Eds.), Late Ceno-zoic Drainage History of the Southwestern Great Basin and Lower Colorado River Region: Geologic and Biotic Perspectives. Spec Pap, Geol Soc Am 439. pp. 335-353.

Krijgsman, W., Garcés, M., Langereis, C.G., Daams, R., van Dam, J., van der Meulen, A.J., Agustí, J., Cabrera, L., 1996. A new chronology for the middle to late Miocene continental record in Spain. Earth Planet. Sci. Lett. 142, 367-380. https://doi.org/10. 1016/0012-821X(96)00109-4.

Larson, P.H., Meek, N., Douglass, J., Dorn, R.I., Seong, Y.B., 2017. How rivers get across mountains: transverse drainages. Ann. Am. Assoc. Geograph. 107 (2), 274-283. https://doi.org/10.1080/24694452.2016.1203283.

Lautensach, H., 1932. Portugal, auf grund eigener Reisen und der Literatur/dargest. In: A. Petermann's Mitteilungen aus Justus Perthes' Geographischer Anstalt, Ergänzungsheft. vol. 213 (Perthes, Gotha)

Lautensach, H., 1987. As características fundamentais da Geomorfologia. In: Ribeiro, O. Lautensach, H., Daveau, S. (Eds.), Geografia de Portugal. I. A Posição Geográfica e o Território, Lisboa, pp. 121-166.

Maddy, D., Bridgland, R., Green, P., 2000. Crustal uplift in southern England: evidence from the river terrace records. Geomorphology 33, 167-181.

Martín Serrano, A., 1988. Sobre la positión de la raña en el contexto morfodinámico de la Meseta. In: Planteamientos Antiguos y Tendencias Actuales. Boletin Geológico y Minero xcix-vi, pp. 855-870.

Martín Serrano, A., 1991. La definicion y el encajamiento de la red fluvial actual sobre el Macizo Hesperico en el marco de su geodinamica alpina. Rev. de la Soc. Geo. de Esp. 4, 337-351.

Martín Serrano, A., 1994. El relieve del Macizo Hesperico; genesis y cronologia de los principales elementos morfologicos. Cuader. do Lab. Xeoloxico de Laxe 19, 37-55. https://core.ac.uk/download/pdf/61898850.pdf.

Martins, A.A., Cunha, P.P., Gomes, A.A., 2018. Contribuição da análise do perfil longitudinal de tributários do rio Douro português para a identificação do perfil longitudinal do ancestral rio Douro, prévio à etapa de encaixe da rede hidrográfica. In: Maio de 2018, Crato (Brazil). Anais do XII Sinageo, pp. 1-8. http://www.sinageo.org. br/2018/trabalhos/1/1-575-2149.html.

Mather, A.E., 2000. Adjustment of a drainage network to capture induced base-level change: an example from the Sorbas Basin, SE Spain. Geomorphology 34, 271-289. https://doi.org/10.1016/S0169-555X(00)00013-1.

Meek, N., Douglass, J., 2001. Lake overflow: an alternative hypothesis for Grand Canyon incision and development of the Colorado River. In: Young, R.A., Spamer, E.E. (Eds.), Colorado River: Origin and Evolution. 12. Grand Canyon Assoc, Monogr, pp. 
199-204.

Menges, C.M., 2008. Multistage late Cenozoic evolution of the Amargosa River drainage, southwestern Nevada and eastern California. In: Reheis, M.C., Menges, C.M., Hershler, R., Miller, D.M. (Eds.), Late Cenozoic Drainage History of the Southwestern Great Basin and Lower Colorado River Region: Geologic and Biotic Perspectives. Geological Society of America Special Paper 439. pp. 39-90.

Miller, K.G., Kominz, M.A., Browning, J.V., Wright, J.D., Mountain, G.S., Katz, M.E., Sugarman, P.J., Cramer, B.S., Christie-Blick, N., Pekar, S.F., 2005. The phanerozoic record of global sea-level change. Science 310, 1293-1298. https://doi.org/10.1126/ science.1116412.

Pais, J., Cunha, P.P., Pereira, D., Legoinha, P., Dias, R., Moura, D., Brum da Silveira, A., Kullberg, J.C., González-Delgado, J.A., 2012. The Paleogene and Neogene of Western Iberia (Portugal). In: A Cenozoic record in the European Atlantic domain. SpringerBriefs in Earth Sciences, pp. 158. https://doi.org/10.1007/978-3-64222401-0.

Perea, H., Cabral, J., Figueiredo, P.M., Besana-Ostman, G., Brum da Silveira, A., Cunha, P.P., Gomes, A., Lopes, F.C., Pereira, D., Rockwell, T., 2010. Quaternary seismic activity of the Vilariça fault (NE Portugal): preliminary results of a paleoseismological study. In: Actas do VIII Congresso Nacional de Geologia, e-Terra. 11. pp. 4. http://metododirecto.pt/CNG2010/index.php/vol/article/view/279/238.

Pereira, D.I., 1997. Sedimentologia E Estratigrafia Do Cenozóico De Trás-Os-Montes Oriental (Ne Portugal). Ph.D Thesis. Univ. do Minho, pp. 341.

Pereira, D.I., Azevedo, T.M., 1995. Quaternary evolution of Vilariça Graben, Trás-osMontes, NE Portugal. Cad Lab Xeoloxico.de Laxe 20, 123-137.

Pereira, D.I., Alves, M.I.C., Araújo, M.A., Cunha, P.P., 2000. Estratigrafia e interpretação paleogeográfica do Cenozóico continental do norte de Portugal. Ciên. da Terra 14, 73-82. http://cienciasdaterra.novaidfct.pt/index.php/ct-esj/article/view/181/184.

Pereira, D.I., Pereira, P., Brilha, J., Cunha, P.P., 2015. The Iberian Massif Landscape and Fluvial Network in Portugal: a geoheritage inventory based on the scientific value. Proc. Geol. Assoc. 126, 252-265. https://doi.org/10.1016/j.pgeola.2015.01.003.

Pérez-González, A., 1982. Neógeno y Cuaternario de la llanura manchega y sus relaciones con la cuenca del Tajo. Tesis Doctoral. vol. 179/82. Universidad Complutense de Madrid, pp. 787.

Pérez-González, A., Gallardo, J., 1987. La Raña al sur de la Somosierra y Sierra de Ayllon; un piedemonte escalonado del Villafranquiente medio. Geogaceta 2, 29-32.

Rockwell, T., Fonseca, J., Madden, C., Dawson, T., Owen, L.A., Vilanova, S., Figueiredo, P., 2009. Paleoseismology of the Vilariça segment of the Manteigas-Bragança fault in Northeastern Portugal. Geol. Soc. Lond. Spec. Publ. 316, 237-258. https://doi.org/ 10.1144/SP316.15.

Silva, C.M., Landau, B., Domènech, R., Martinell, J., 2010. Pliocene Atlantic molluscan assemblages from the Mondego Basin (Portugal): age and palaeoceanographic implications. Palaeogeogr. Palaeoclimatol. Palaeoecol. 285, 248-254. https://doi.org/ 10.1016/j.palaeo.2009.11.016.

Silva, P.G., Roquero, E., López-Recio, M., Huerta, P., Martínez-Graña, A.M., 2017. Chronology of fluvial terrace sequences for large Atlantic rivers in the Iberian Peninsula (Upper Tagus and Duero drainage basins, Central Spain). Quat. Sci. Rev. 166, 188-203. https://doi.org/10.1016/j.quascirev.2016.05.027.

Solé, L., 1952. La Meseta. In: Teran, M. (Ed.), Geografia de España y Portugal. T.I. Geografia Física de Espãna. Montaner y Simon, pp. 158-328 (Barcelona).

Soria-Jáuregui, A., Jiménez-Cantizano, F., Antón, L., 2018. Geomorphic and tectonic implications of the endorheic to exorheic transition of the Ebro River system in
Northeast Iberia. Quat. Res. 91 (2), 472-492. https://doi.org/10.1017/qua.2018.87.

Stokes, M., 2008. Plio-Pleistocene drainage development in an inverted sedimentary basin: Vera basin, Betic Cordillera, SE Spain. Geomorphology 100 (1-2), 193-211.

Stokes, M., Mather, A.E., 2003. Tectonic origin and evolution of a transverse drainage: the Rio Almazora. In: Betic Cordillera, southeast Spain: Geomorphology. 50. pp. 59-81. https://doi.org/10.1016/S0169-555X(02)00208-8.

Stokes, M., Mather, A.E., Harvey, A.M., 2002. Quantification of river-capture-induced base-level changes and landscape development, Sorbas Basin, southeastern Spain. In: Jones, S.J., Frostick, L.E. (Eds.), Sediment Flux to Basins: Causes, Controls and Consequences. Geological Society of London, London, pp. 23-35. https://doi.org/10. 1144/GSL.SP.2002.191.01.03.

Stokes, M., Cunha, P.P., Martins, A.A., 2012. Techniques for analysing river terrace sequences. Geomorphology 165-166, 1-6. https://doi.org/10.1016/j.geomorph.2012. 03.022 .

Stokes, M., Mather, A., Rodes, A., Kearsey, S., Lewin, S., 2018. Anatomy, Age and Origin of an Intramontane Top Basin Surface (Sorbas Basin, Betic Cordillera, SE Spain). Quaternary 1, 15. https://doi.org/10.3390/quat1020015.

Struth, L., Garcia-Castellanos, D., Viaplana-Muzas, M., Vergés, J., 2019. Drainage network dynamics and knickpoint evolution in the Ebro and Duero basins: from endorheism to exorheism. Geomorphology 327, 554-571. https://doi.org/10.1016/j.geomorph. 2018.11.033.

Tchakerian, V.P., Lancaster, N., 2002. Late Quaternary arid/humid cycles in the Mojave Desert and western Great Basin of North America. Quat. Sci. Rev. 21 (7), 799-810.

Teixeira, C., Perdigão, J., Assunção, C.T., 1962. Carta geológica de Portugal à escala de 1/ 50000. In: Notícia Explicativa da Folha 13-A (Espinho). Serviços Geológicos de Portugal, pp. 28 Lisboa.

Tockner, K., Uehlinger, U., Robinson, C.T., 2009. Rivers of Europe. Elsevier, pp. 728.

Twidale, C.R., 2004. River patterns and their meaning. Earth Sci. Rev. 67, 159-218. https://doi.org/10.1016/j.earscirev.2004.03.001.

Vieira, M., Poças, E., Pais, J., Pereira, D., 2011. Pliocene Flora from S. Pedro Da Torre Deposits. vol. 33. Geodiversitas, Minho, NW Portugal, pp. 71-85. https://doi.org/10. 5252/g2011n1a5.

Vieira, M., Pound, M.J., Pereira, D.I., 2018. The late Pliocene palaeoenvironments and palaeoclimates of the western Iberian Atlantic margin from the Rio Maior flora. Palaeogeogr. Palaeoclimatol. Palaeoecol. 495, 245-258. https://doi.org/10.1016/j. palaeo.2018.01.018.

Vilanova, S.P., Nemser, E.S., Besana-Ostman, G.M., Bezzeghoud, M., Borges, J.F., Brum da Silveira, A., Cabral, J., Carvalho, J., Cunha, P.P., Dias, R.P., Madeira, J., Lopes, F.C. Oliveira, C.S., Perea, H., García-Mayordomo, J., Wong, I., Arvidsson, R., Fonseca, J.F.D.B., 2014. Incorporating descriptive metadata into seismic source zone models for seismic-hazard assessment: a case study of the Azores-west Iberian region. Bull. Seismol. Soc. Am. 104 (3), 1212-1229. https://doi.org/10.1785/0120130210.

Wintle, A.G., Murray, A.S., 2006. A review of quartz optically stimulated luminescence characteristics and their relevance in single-aliquot regeneration dating protocols. Radiat. Meas. 41, 369e391.

Young, R.A., Spamer, E.E., 2001. Colorado River origin and evolution. In: Young, R.A., Spamer, E.E. (Eds.), Colorado River origin and evolution: Grand Canyon. Grand Canyon Association, pp. 7-15.

Zilhão, J., 1997. Arte Rupestre e Pré-História do Vale do Côa. Trabalhos de 1995-1996. Ministério da Cultura, Lisboa, pp. 453. http://www.arte-coa.pt/Ficheiros/ Bibliografia/1784/1784.pt.pdf. 